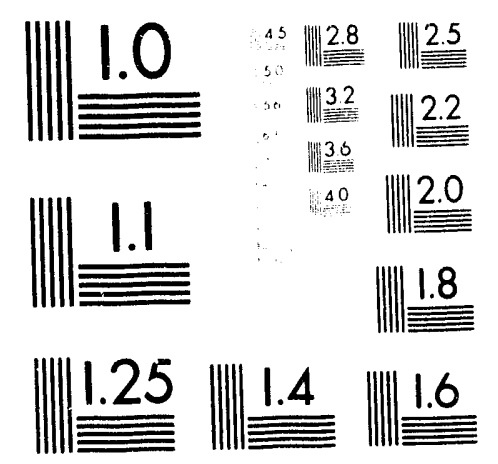



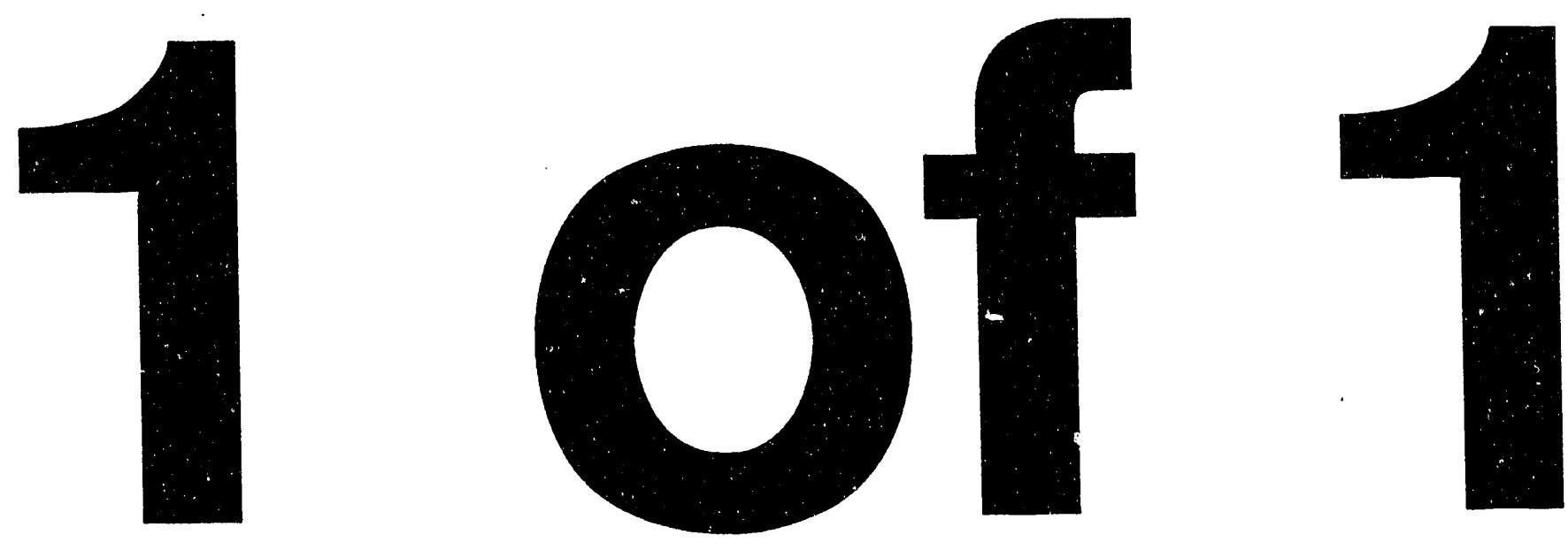
UCRL-CR-113692

\section{Exploratory Depth-of-Burst Experiments}

H. Reichenbach

K. Behrens

A.L. Kuh]

December 1991

MeTre

aIstRiaution of rHIS nocument

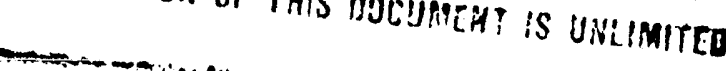




\section{DISCIAINIE}

Work performed under the auspices of the C.S. Department of Fenergs by laurence lisermore National laboratory under contract number $W-7405-F-N(i-48$.

I his document was prepared as an account of work sponsored bs an agency of the I nited States Government. Veither the I nited States (iovernment nor the I nis ersity of (alifornia nor any of their employees, makes any warrants. espress or implied, or assumes an! legal liability or responsihility for the accuraces. completeness, or uscefulness of any information. apparatus, product, or srocess disclosed. or represents that its use would not infringe privately owned rights. Reference herein to any specific commercial products. process, or service by trade name, trademarh. manufacfurer, or otherwise, does not necessarils constitute or impls its endorsement. recommendation. or favoring bs the I nited States (ionernment or the I niversity of California. The riews and opinions of authors espressed herein don not necessarily state or reflect those of the I nited States Government or the Linicersity of (alifornia, and shall not be used for advertising or product endorsement purpeses. 


\title{
E 16/91
}

\section{Exploratory \\ Depth-of-Burst Experiments}

\author{
H. Reichenbach
}

K. Behrens
A. Kuhl

wiviva

AUG 301993

OSTI 


\title{
Exploratory Depth-of-Burst Experiments
}

\author{
H. Reichenbach \\ K. Behrens \\ Ernst-Mach-Institut, \\ Freiburg, Germany \\ A. Kuhl \\ Lawrence Livermore National Laboratories, \\ Los Angeles, CA
}

Interim Report 


\section{EXPLORATORY DEPTH-OF-BURST EXPERIMENTS}

H. Reichenbach

K. Behrens

Ernst-Mach-Institut

Eckerstr. 4

7800 Freiburg, FRG

\section{A. Kuhl}

Lawrence Livermore National Laboratories

5230 Pacific Concourse Drive

Los Angeles, CA 90045

12 December 1991

Interim Report

CONTRACT No. DNA 001-91-C-0039

THIS WORK WAS SPONSORED BY THE DEFENSE NUCLEAR AGENCY

UNDER RDT\&E RMSS CODE B 4662 D RA RG 003524400 A AC

Prepared for

Director

DEFENSE NUCLEAR AGENCY

Washington, DC 20305-1000 


\section{SUMMARY}

This reports describes the first small-scale explosion experiments with aerated grout (i.e., YTONG). Apart from data referring to crater depth and volume versus depth of burst (DOB), isobaric DOB curves in the range of $1.5 \mathrm{psi} \leq \mathrm{p} \leq 15 \mathrm{psi}$ were established. The comparison with previous $\mathrm{HOB}$ values shows that the ground range to a given overpressure is considerably reduced with increasing depth of burst.

We plan to continue the airblast investigations with different types of soil materials. 
TABLE OF CONTENTS

Section

Page

Summary $\quad 2$

List of Illustrations 4

1 Introduction 7

2 Test Set Up 8

2.1 Soil Material $\quad 8$

2.2 Installation of the Charge 9

2.3 Installation into the Explosion Chamber 9

3 Test Matrix 11

4 Test Results 13

4.1 Crater 13

4.2 Pressure Measurements 15

5 Conclusions 18

6 List of References 19 


\section{LIST OF ILLUSTRATIONS}

Figure

Page

1 Microscopic photographs showing the fracture surface of aerated grout (YTONG)

2 Installation of the $0.5-\mathrm{g}$ charge into aerated grout and shock-isolated mounting of the set-up into the explosion chamber

3 Definition of depth of burst, DOB, and overburden, $\mathrm{H}$

4 General view showing the construction of the YTONG holder

5 Position of the shock-isolated pressure gauges, MK1 - MK16

6 Aerated-grout specimen after test (still embedded in steel tube)

7 Apparent crater dimensions of different charge geometries and definition of apparent and true crater depths, resp.

8 Examples of craters at different depths of burst

9 True crater contours

10 True crater depth vs depth of burst

11 True crater volume vs depth of burst 


\section{LIST OF ILLUSTRATIONS (CONTINUED)}

Figure

Page

12 Examples of crater ejecta at different

depths of burst

30

13 Comparison of YTONG crater depth with other soil material [3]

14 Pressure-time records at different ground ranges (test 723),

MK1, MK3, MK5, MK7, MK9, MK11; DOB = -0.5 cm;

YTONG; $\mathrm{W}=0.5 \mathrm{~g}$

15 Pressure-time records at different ground ranges (test 722),

MK1, MK3, MK5, MK7, MK9, MK11; DOB = $0 \mathrm{~cm}$;

YTONG; $W=0.5 \mathrm{~g}$

16 Pressure-time records at different ground ranges (test 737),

MK1, MK3, MK5, MK7, MK9, MK11; DOB = $0.5 \mathrm{~cm}$;

YTONG; $\mathrm{W}=0.5 \mathrm{~g}$

17 Pressure-time records at different ground ranges (test 717),

MK1, MK3, MK5, MK7, MK9, MK11; DOB = $1.0 \mathrm{~cm}$;

YTONG; $\mathrm{W}=0.5 \mathrm{~g}$

18 Pressure-time records at different ground ranges (test 719),

MK1, MK3, MK5, MK7, MK9, MK11; DOB = $2.0 \mathrm{~cm}$;

YTONG; $\mathrm{W}=0.5 \mathrm{~g}$

19 Pressure-time records at different ground ranges (test 720),

MK1, MK3, MK5, MK7, MK9, MK11; DOB = $3.0 \mathrm{~cm}$;

YTONG; $\mathrm{W}=0.5 \mathrm{~g}$ 


\section{LIST OF ILLUSTRATIONS (CONTINUED)}

Figure

Page

20 Pressure-time records at different ground ranges (test 721),

MK1, MK3, MK5, MK7, MK9, MK11; DOB = $4.0 \mathrm{~cm}$;

YTONG; $W=0.5 \mathrm{~g}$

21 Pressure-time records at different ground ranges (test 725),

$\mathrm{MK} 1, \mathrm{MK} 2, \mathrm{MK} 3, \mathrm{MK} 4, \mathrm{MK} 6, \mathrm{MK} 8 ; \mathrm{DOB}=5.0 \mathrm{~cm}$;

YTONG; $\mathrm{W}=0.5 \mathrm{~g}$

22 Pressure-time and impulse-time records at different ground ranges (test 717 ),

MK1, MK3, MK5, MK7, MK9, MK11; DOB = $1.0 \mathrm{~cm}$;

YTONG; $\mathrm{W}=0.5 \mathrm{~g}$

23 Peak overpressure vs ground range at different

depths of burst; YTONG

24 Positive impulse vs ground range at different

depths of burst; YTONG

25 Isobaric depth-of-burst curves

26 Comparison of $\mathrm{DOB}$ results with peak-overpressure HOB curves for hydrodynamically-smooth surface (Makrolon).

- Low-pressure regime

27 Comparison of DOB results with peak-overpressure HOB curves for hydrodynamically-smooth surface (Makrolon).

- Intermediate-pressure regime 


\section{SECTION 1}

\section{INTRODUCTION}

While much airblast data are available for height-of-burst (HOB) effects (c.g., References 1 - 4), systematic airblast data for depth-of-burst (DOB) effects is much more limited (References 5 - 11). The legitimate question has therefore been asked whether the 0.5-g NP charges that proved to be successful for HOB tests are also suitable for DOB tests. The main interest was to be to investigate blast wave data in order to be able to complete the isobaric $\mathrm{HOB}$ curves for DOB cases. The data recording concerning crater depth and crater volume are of secondary importance. As is known, not all physical data (e.g., gravity) can. on a model scale, be chosen in accordance with the requirements of the similarity law's for crater formation.

Therefore, the significance of DOB model tests is mainly to determine the influence of different parameters (e.g., soil material, overburden) on the airblast environment. Smallscale tests seem to be highly suitable for such parametric studies, for example:

(a) They are inexpensive, therefore parametric studies are feasible.

(b) They can be performed in a relatively short time.

(c) The properties of the simulated soil material can easily be controlled.

(d) Tests can be repeated under identical conditions.

(e) Laboratory measuring techniques can be applied, including high-speed photographic visualization.

(f) The present test equipment can be used, with only slight alterations.

In the present report the test set up will be described and first DOB results will be presented. It will thus be proved that small-scale tests can be used to solve some of the current physical DOB problems. 


\section{SECTION 2}

\section{EXPERIMENT DESIGN}

The first objective was simply to check the feasibility of DOB experiments. Therefore only minor alterations were made to the existing explosion chamber (see Ref. 1). For instance, the neasuring system installed in the roof plate of the chamber remained basically the same. The result of this was that the DOB experiments were carried out - as it is the case with our HOB tests - upside down.

\subsection{SOIL MATERIAL.}

Because of the geometrical arrangement, the simulated soil had to be cohesive. The material chosen for the initial DOB tests was an aerated grout (i.e., foam concrete with a German trade name YTONG). This material, which is used in house construction and has a good heal insulation, is easy to treat mechanically. The uraterial properties of YTONG are listed in Table 1.

Table 1. Material Properties of YTONG.

$\begin{array}{lll}\text { specific weight: } & 0.4 \mathrm{~g} / \mathrm{cm}^{3} & \left(25 \mathrm{pound} / \mathrm{ft}^{3}\right) \\ \text { Young's modulus: } & 1300 \mathrm{~N} / \mathrm{mm}^{2} & \left(1.885 \cdot 10^{5} \mathrm{psi}\right) \\ \text { compressive strength: } & 2.5 \mathrm{~N} / \mathrm{mm}^{2} & (363 \mathrm{psi}) \\ \text { heat conductivity: } & 0.12 \mathrm{~W} / \mathrm{mK} & \\ \text { grain size } & 0.02-0.2 \mathrm{~mm} & \end{array}$

Microscopic photographs showing the fracture surfaces of the aerated grout (YTONG) are presented in Figure 1. The grain size of about $0.1 \mathrm{~mm}$ can be estimated from the inserted scale. The material is extremely porous. The specific weight is therefore only $0.4 \mathrm{~g} / \mathrm{cm}^{3}$.

YTONG is usually supplied in blocks of $59.9 \mathrm{~cm} \times 25.0 \mathrm{~cm} \times 24.9 \mathrm{~cm}$. With the help of a core drill, cylinders were bored and finished on the lathe. Thus the foam concrete. despite its granular structure, achieves a relatively smooth surface. During the drilling and turning water is added. YTONG absorbs the moisture. To achieve reproducible results, only those foam 
concrete cylinders have been used for the experiments that were stored and dried in the laboratory for several days. They were only used when there were no further changes in the daily weight checks.

\subsection{INSTALLATION OF THE CHARGE.}

The installation of the $0.5-\mathrm{g}$ charge is sketched in Fig. 2. A hole with a diameter of about $10.4 \mathrm{~mm}$ is drilled concentrically into the YTONG cylinder. The bore depth is chosen in such a way that the required overburden remains constant. With the help of a special tool, a hemispherical deepening with a radius of $5 \mathrm{~mm}$ is made at the end of the bore. The charge (diameter $1 \mathrm{~cm}$ ) is inserted through the bore channel and the correct position of the charge is controlled with the length of the supply wires. The remaining hollow space in the bore channel is filled with pulverized aerated grout to obtain the necessary backfilling. Finally, the bore opening is closed with an adhesive.

This procedure guarantees that the overburden remains in the original material condition and is not altered, as it is generally the case with free-field DOB experiments. There, the charge is usually sunk into the soil from the earth surface.

After the YTONG cylinder was prepared as described, it was inserted into a steel tube with an inner diameter of $100.5 \mathrm{~mm}$ so that the plane face ends flush with the rim of the tube.

The designations used in this report are explained in Fig. 3.

\subsection{INSTALLATION INTO THE EXPLOSION CHAMBER.}

Figure 2 schematically shows the installation of an YTONG cylinder set into a steel tube. To reduce the transmission of acceleration impulses created by the detonation of the charge, the steel tube has been installed shock-isolated into the explosion chamber. The mounting of the pressure gauges, which proved so worthwhile with the HOB tests, was retained.

Figure 4 gives a general view showing not only the construction of the steel cylinder but also the shielding of the high-voltage ignition circuit that runs in a type of Faraday cage. This isolation technique was necessary to keep the electromagnetic interferences coming from the ignition circuit as far away from the pressure gauges and their supplies as possible. 
The position of the pressure gauge in relation to ground zero is depicted in Fig. 5. Gauge MK1 is $90 \mathrm{~mm}$ away from GZ. The distance between gauges MK1 to MK13 is $60 \mathrm{~mm}$ each. Gauges MK14, MK15 and MK16 are arranged in a distance of $85 \mathrm{~mm}, 99.4 \mathrm{~mm}$ and 150 $\mathrm{mm}$, respectively. They are not on the same radius as gauges MK1 to MK13.

No alterations were made to the recording equipment and the optical arrangement for the shadow and schlieren photographs (single photographs). They are described in Ref. 1. 


\section{SECTION 3}

\section{TEST MATRIX}

The test matrix is presented in Table 2. We found that experiments with DOB $>5 \mathrm{~cm}$ did not create significant pressure pulses. Note that the DOB is counted positive from the surface to the installation point, so that $\mathrm{DOB}=-0.5 \mathrm{~cm}$ indicates a charge tangent above the surface. As before, the diameter of the $0.5-\mathrm{g}$ explosive sphere is $1 \mathrm{~cm}$.

Table 2. Test Matrix.

\begin{tabular}{|l|l|l|l|l|l|l|}
\hline $\begin{array}{l}\text { DOB } \\
{[\mathrm{cm}]}\end{array}$ & $\begin{array}{l}-0.5 \\
(\text { tangent })\end{array}$ & 0 & 0.25 & 0.35 & 0.5 & 1.0 \\
\hline Test No. & $\begin{array}{l}723 \\
726\end{array}$ & 722 & 735 & 736 & $\begin{array}{c}737 \\
738\end{array}$ & 717 \\
\hline
\end{tabular}

\begin{tabular}{|c|c|c|c|c|c|c|}
\hline $\begin{array}{l}\text { DOB } \\
{[\mathrm{cm}]}\end{array}$ & 1.5 & 2.0 & 2.5 & 3.0 & 4.0 & 5.0 \\
\hline Test No. & 740 & $\begin{array}{l}712 \\
713 \\
719\end{array}$ & $\begin{array}{l}741 \\
742\end{array}$ & $\begin{array}{l}718 \\
720\end{array}$ & 721 & $\begin{array}{l}724 \\
725\end{array}$ \\
\hline
\end{tabular}

To get a better idea about how the measuring data fit in with previous full-scale experiments. Table 3 presents some DOB tests, for which airblast data were also determined. The charge weights were between 8 and 20 tons, i.e., about 7 orders of magnitude higher than for our 0.5-g charges. The EMI experiments have also been inserted in Table 3, the scaling was $\mathrm{W}^{1 / 3}$. As shown in the table, the additional objective of our tests is to determine the transition of the airblast data from HOB to DOB. 
Table 3. HE Events with Airblast Data.

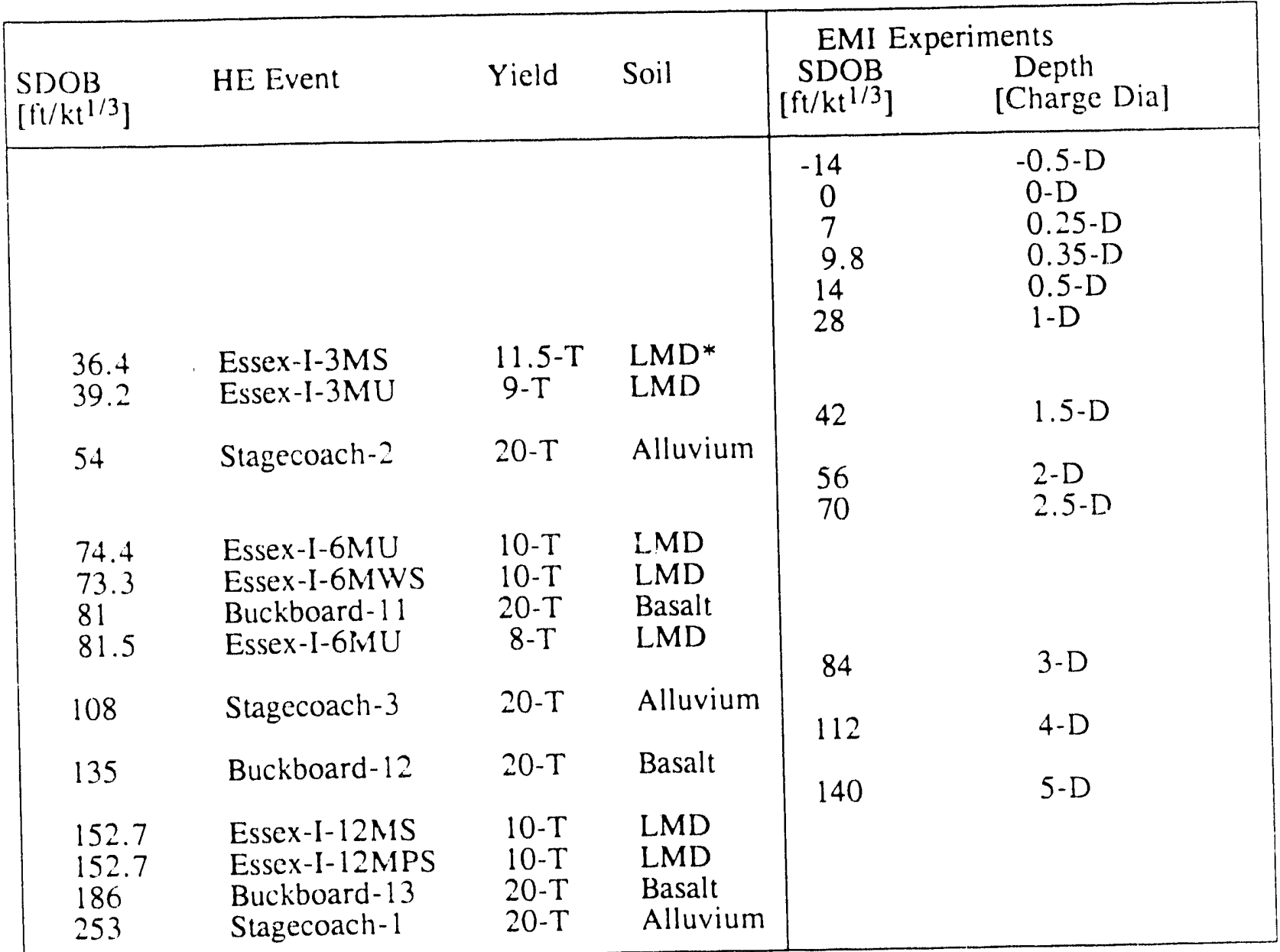

*LMD = Layered Marine Deposits 


\section{SECTION 4}

\section{TEST RESULTS}

\subsection{CRATER.}

The depth of the crater, $d_{k}$. which is formed at the detonation of the charge. has been measured with a caliper rule. Note that, with our test set up, the true crater depth is measured, because the lose crater material can no longer fall back into the crater, as it is the case with free-field tests. A definition of apparent and true crater depths, resp., is given in Fig. 7. The crater volume, $V_{k}$, was determined by the difference in weight, $\Delta G$, of the aerated grout before and after the experiment. Since the specific weight $\gamma_{\text {cyl }}$ was determined for each YTONG cylinder before the bore hole, we have

$$
\mathrm{V}_{\mathrm{k}}=\Delta \mathrm{G} / \mathrm{Y}_{\mathrm{cyl}}
$$

Table 4 gives the results obtained so far, while Fig. 6 shows the crater of an YTONG sample that is still to be found in the steel cylinder. Some photographs of craters at different DOB have been compiled in Fig. 8. Figure 9 depicts some typical crater cross-sections measured according to eye judgement.

The crater form turned out to be axially symmetrical in all experiments. It is remarkable that in about one third of the DOB there is an edge that is more or less distinct for all DOB tests. It also has to be pointed out that the experiments at the same DOB show very little scatter in the crater dimensions.

Figure 10 shows the crater depth as a function of the DOB. Figure 11 shows that the crater volume increased linearly with the depth of burst:

$$
v_{k}=50.70 D O B+53.45 \quad(\text { for } D O B \leq 5 \mathrm{~cm})
$$

where $\left[V_{k}\right]=\mathrm{cm}^{3}$ and $[D O B]=\mathrm{cm}$ for $0.5-\mathrm{g}$ charge. It would seem reasonable that the amount of charge energy absorbed by the cratering process would be linearly related to the crater volume. Hence Fig. 11 indicates that the amount of charge energy available to drive the airblast wave decreases with depth of burst. This is certainly born out by the pressure measurements. 
A single picture has been made for each DOB test. In these photographs, the shock front is visible and the crater ejecta can usually be seen as a black cone. Some typical cases are given in Fig. 12.1 For high DOB ( $\geq 4 \mathrm{~cm}$ ) it is noticeable that big lumps of aerated grout are apparently hurled out of the crater and gas jets appear in between. In these cases, no shock front is visible. This leads one to assume that the pressure distribution takes place in the form of compression waves.

To investigate how the measuring values for YTONG fit in with the results for real soil materials, data were used from [4]. Figure 13 shows this comparison. In [4], the crater depths are scaled with $\mathrm{W}^{5 / 16}$, so that this scale was chosen for the conversion of our data. Of all the soil materials given in [4], sand has the closest resemblance to aerated groul (YTONG), although the density of sand is higher.

Considering that the EMI experiments determine the true crater depth and not the apparem crater depth, the deviation of the YTONG curve from the sand curve is absolutely plausible. As expected, it has the same DOB for higher crater depths. It is also noticeable that the slope of the two curves show a good agreement.

We may conclude, with caution, that the model tests allow qualitative statements and that parametric studies are suitable for a better understanding of the influences of different soil parameters on the crater formation.

1 On some partial pictures the silhouette of a tank can be seen. These photographs were made when dealing with a different problem that will be presented in a separate technical note. 
Table 4. Crater Depth and Crater Volume.

\begin{tabular}{|c|c|c|c|c|c|c|}
\hline $\begin{array}{l}\text { DOB } \\
{[\mathrm{cm}]}\end{array}$ & Test No. & $\begin{array}{l}\text { Depth } \\
{[\mathrm{cm}]}\end{array}$ & $\begin{array}{l}\text { Volume } \\
{\left[\mathrm{cm}^{3}\right]}\end{array}$ & $\begin{array}{l}\text { Scaled } \\
\text { DOB } \\
{\left[\mathrm{m}^{\prime} / \mathrm{kg}^{1 / 3}\right]}\end{array}$ & $\begin{array}{l}\text { Scaled } \\
\text { Depth } \\
{\left[\mathrm{m}^{\prime} / \mathrm{kg}^{1 / 3}\right]}\end{array}$ & $\begin{array}{l}\text { Scaled } \\
\text { Volume } \\
{\left[\mathrm{m}^{3} / \mathrm{kg}\right]}\end{array}$ \\
\hline-0.5 & $\begin{array}{l}723 \\
726\end{array}$ & $\begin{array}{l}1.8 \\
1.8\end{array}$ & $\begin{array}{l}14.3 \\
16.3\end{array}$ & -0.0630 & $\begin{array}{l}0.227 \\
0.227\end{array}$ & $\begin{array}{l}0.0286 \\
0.0326\end{array}$ \\
\hline 0 & 722 & 2.7 & 32.2 & 0 & 0.340 & 0.0644 \\
\hline 0.35 & 735 & 2.7 & 83.7 & 0.0315 & 0.340 & 0.167 \\
\hline 0.35 & 736 & 2.9 & 70.9 & 0.0441 & 0.365 & 0.142 \\
\hline 0.5 & $\begin{array}{l}737 \\
738\end{array}$ & $\begin{array}{l}3.1 \\
3.0\end{array}$ & $\begin{array}{l}76.7 \\
85.7\end{array}$ & 0.0630 & $\begin{array}{l}0.391 \\
0.378\end{array}$ & $\begin{array}{l}0.153 \\
0.171\end{array}$ \\
\hline 1.0 & 717 & 4.0 & - & 0.126 & 0.504 & - \\
\hline 1.5 & 740 & 5.0 & 163.1 & 0.189 & 0.630 & 0.326 \\
\hline 2.0 & $\begin{array}{l}712 \\
713 \\
719\end{array}$ & $\begin{array}{l}5.3 \\
5.3 \\
5.0\end{array}$ & $\begin{array}{c}- \\
- \\
177.1\end{array}$ & 0.252 & $\begin{array}{l}0.668 \\
0.668 \\
0.630\end{array}$ & $\begin{array}{c}- \\
- \\
0.354\end{array}$ \\
\hline 2.5 & $\begin{array}{l}741 \\
742\end{array}$ & $\begin{array}{l}5.9 \\
6.0\end{array}$ & $\begin{array}{l}179.1 \\
194.9\end{array}$ & 0.315 & $\begin{array}{l}0.743 \\
0.756\end{array}$ & $\begin{array}{l}0.358 \\
0.390\end{array}$ \\
\hline 3.0 & $\begin{array}{l}718 \\
720\end{array}$ & $\begin{array}{l}6.4 \\
6.2\end{array}$ & $\begin{array}{l}197.1 \\
193.0\end{array}$ & 0.378 & $\begin{array}{l}0.806 \\
0.781\end{array}$ & $\begin{array}{l}0.394 \\
0.386\end{array}$ \\
\hline 4.0 & 721 & 7.2 & 223.2 & 0.504 & 0.907 & 0.446 \\
\hline 5.0 & $\begin{array}{l}724 \\
725\end{array}$ & $\begin{array}{l}8.5 \\
9.0\end{array}$ & $\begin{array}{l}307.4 \\
315.8\end{array}$ & 0.630 & $\begin{array}{l}1.071 \\
1.134\end{array}$ & $\begin{array}{l}0.615 \\
0.632\end{array}$ \\
\hline
\end{tabular}

\subsection{PRESSURE MEASUREMENTS.}

Figures $14,15,16$, and 17 show examples of pressure recordings at $\mathrm{DOB}=-0.5,0.0 .5,1$, $2,3,4$, and $5 \mathrm{~cm}$, respectively. The positions of the measuring channels can be taken from Fig. 4. 
Note that the scale for the different recording curves (Figs. 14 - 21) is not the same, because the peak overpressure varies strongly with distance and DOB. To emphasize the strong fall of the peak overpressure along with the increasing distance from ground zero, the same scale was used for test $717, D O B=1 \mathrm{~cm}$, Fig. 22. In addition to the pressure curve in this Figure, the positive phase impulse curve is also given.

At low DOB (Figs. 14 - 17), the pressure curve is similar to an ideal Friedlander function and shows no disturbances. The shock front is sharp. There are no signs of compression waves running ahead of the main wave. The situation varies with increasing DOB (Figs. 19 21). In this case, there is no steep shock front, but one notes two phases of the pressure increase. Both seem to be caused by compression waves. The reason for the first might be the fact that, after the detonation of the charge, the overburden is initially moved like a piston. This may lead to the formation of cracks through which a part of the compressed smoke escapes. Lumps are perforated with cracks and are finally hurled out of the crater clearing the way for a propagation of the main compression wave. However, they keep preventing an uninterrupted propagation so that no uniform shock front can be formed. This may be responsible for the slow pressure increase of the second phase. At lower DOB, the overburden flies off at high velocity and is reduced to very small particles. This is also suggested by the photographs of the crater ejecta. The compressed gas smoke, although delayed with increasing DOB, is therefore suddenly released and can produce a steep shock front.

The dependence of the peak overpressure on DOB and ground range (GR) is shown in a scaled form in Fig. 23. The legends gives the assignment of the symbols to the depth of burst. The test numbers can also be taken from it. For each test, fit functions with the form

$$
\log p=a_{0}+a_{1} \log G R+a_{2}(\log G R)^{2}
$$

have been determined from the measuring values according to the least square method. The curves shown in Fig. 23 correspond to these functions. While the agreement of different experiments at the same $D O B$ for $D O B \leq 3 \mathrm{~cm}$ is excellent (cf. $D O B=-0.5 \mathrm{~cm}, 2.0 \mathrm{~cm}$, $3.0 \mathrm{~cm}$ ), there are major deviations at $\mathrm{DOB}=5 \mathrm{~cm}$. We assign this to the formation of crater ejecta which has a strong influence on the pressure curve in the compression waves. In addition, it is very problematic to compare the well defined peak overpressure of a blast wave to the more random maximum pressure of compression waves (see, e.g., Figs. 17 and 21). 
The same considerations apply to the dependence of the positive impulse of the DOB given in Fig. 24. The measuring data, given in a scaled form, are consistent for $\mathrm{DOB} \leq 3 \mathrm{~cm}$.

By means of the fit functions for the peak overpressure, the distances to a given pressure value can be determined in the usual way. In Fig. 25, some isobaric DOB curves are arranged in scaled coordinates. The values for $\mathrm{HOB}=0.063 \mathrm{~m} / \mathrm{kg}^{1 / 3}$ correspond to charges tangent above the surface. A boundary line at $G R=1.07 \mathrm{~m} / \mathrm{kg}^{1 / 3}$ is drawn in the diagram. It indicates the position of the measuring gauge closest to ground zero. No measuring data are available for sinaller values of GR.

To compare with isobaric HOB curves, the DOB data have been plotted on our previously published diagrams. Figure 26 shows peak pressure height-of-burst curves for a hydrodynamically-smooth surface in the low-pressure regime (taken from Ref. 2, Fig. 7). This diagram has been completed by DOB curves from Fig. 25 that were derived for aerated grout (YTONG). The DOB curves are difficult to distinguish because of the small ordinate scale. With increasing depth of burst, however, the extremely strong attenuation of the blast wave is clearly visible. As a result, the ground ranges in which the given peak overpressures appear are considerably reduced, because the cratering process absorbs energy.

Figure 27 gives a corresponding representation for the intermediate-pressure regime. The $\mathrm{HOB}$ curves are taken from Ref. 2, Fig. 8. One can clearly see in Fig. 27 that for $\mathrm{HOB}=$ 0.0603 (charge tangent to the surface) the ground ranges for YTONG have smaller values than for a hydrodynamically-smooth surface. This points out to the fact that more energy is absorbed in the aerated grout than in a hard material such as Makrolon. 


\title{
SECTION 5
}

\section{CONCLUSIONS}

These exploratory tests have demonstrated the feasibility of performing airblast depth-of-burst experiments at laboratory scale. This method should be used to investigate now the material properties effect the DOB curves. To validate the scalability of the results, laboratory simulations of selected large-scale $\mathrm{HE}$ events (Table 3) should be performed. Hence, experiments with materials that simulate the following soils will be considered:

\author{
Alluvium (silted lake-bed material) \\ Basalt (granite rock) \\ Layered Marine Deposits \\ water-saturated YTONG \\ wet clay
}




\section{SECTION 6}

\section{LIST OF REFERENCES}

1. H. Reichenbach, Laboratory-Scale Airblast Precursor Experiments, Volume III - HOB Studies Micro-Mach Experiments, Defense Nuclear Agency, DNA-TR-85-352-V3 (March 1989).

2. H. Reichenbach, G. Scheklinski-Glück, A.L. Kuhl, Comparison of HOB Curves for 0.5-g NP Charges with Field Test Data and Calculations, $R$ and D Associates, RDA-TR-0263229003-001 (August 1991).

3. J. Petes, Handbook of HE Explosive Effects, DASIAC-TN-86-15 (April 1986).

4. M.M. Swisdak, Explosion Effects and Properties; Part I - Explosion Effects in Air. NSWC/WOL/TR 75-116 (October 1975).

5. Teller, E., Talley, W.K., Higgins, G.H., and Johnson, C.W., The Consiructive Uses of Nuclear Explosives, McGraw-Hill (1968).

6. Harvey, W.T., ESSEX - DIAMOND ORE Research Program, Preliminary Results Report - Essex-1, Phase 1: Nuclear Cratering Device Simulation (Project ESSEX). DNA PR 0002 (WES PR E-74-1), (Apr. 1974).

7. Reisler, R.E., Dettit, B.A., Air Blast From Shallow-Buried Charges, ESSEX I. Phase 2, BRL MR 2656, (Aug. 1976).

8. Vortman, L.J.; Dickinson, J.R., and Fastle, D.L.; Results of Airblast and Temperature Measurements, Project ESSEX 1, Phase 3, SAND76-0531, Sandia Laboratories (Jan. 1977).

9. Rooke, A.D., Jr., ESSEX-DIAMOND ORE Research Program: Apparent Crater Measurements for Simulated Low Yield Nuclear Explosions, Project ESSEX I, Phases 1 and 2, WES MP N-78-3 (Mar. 1978). 
10. Reed, J.W., "Air Blast Cratering Explosions," Proc. of the Third Plowshare Symposium, TID-7695, pp. 169-180, U.S. Atomic Energy Commission (1964).

11. Glasstone, S., and Dolan, P.J., The Effects of Nuclear Weapons, Third Edition, U.S. Department of Defense (1977). 


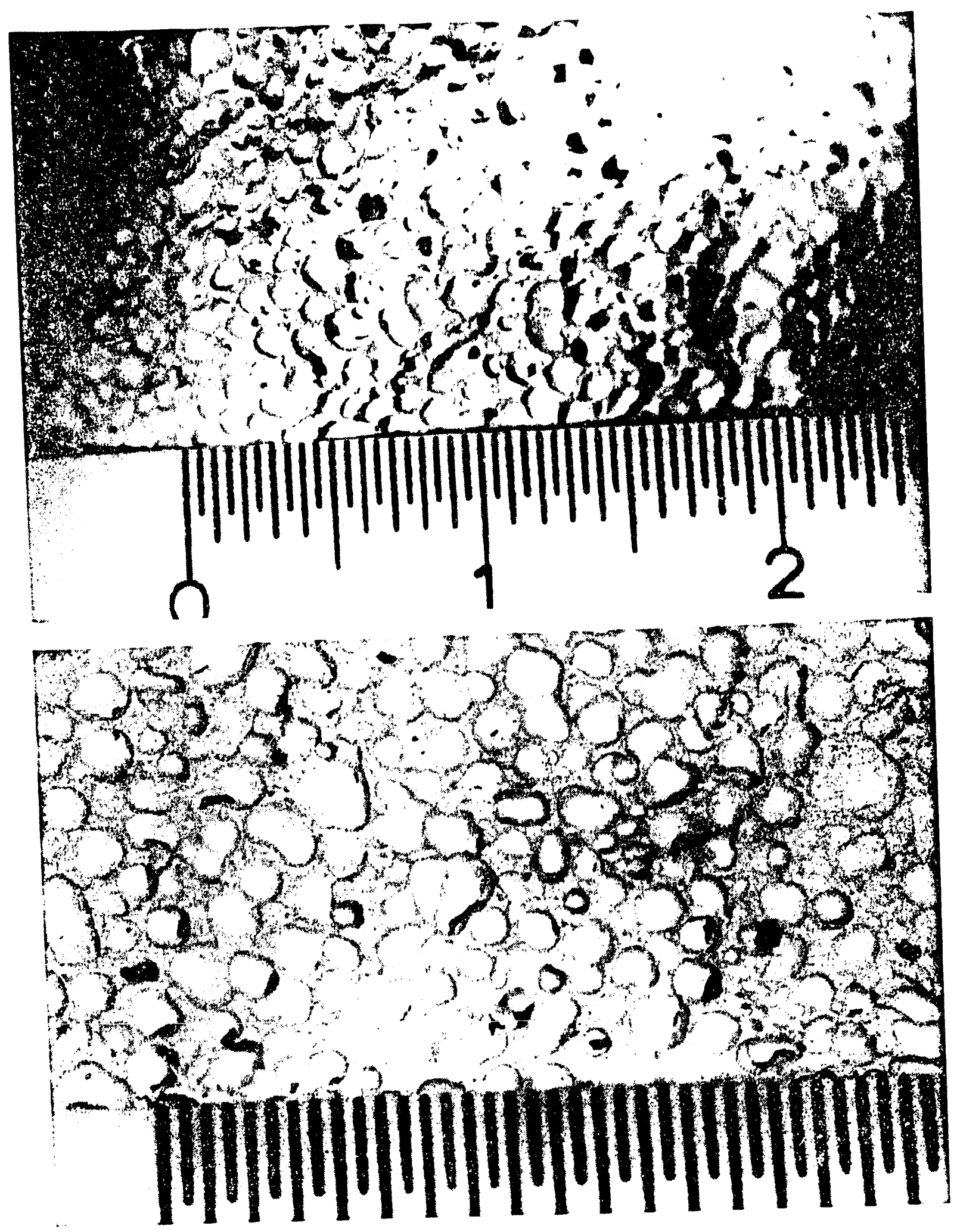

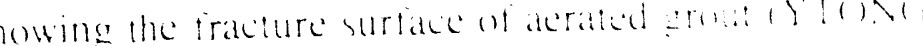
(iradualle marh diskmes: $5.1(x)$ mm. 


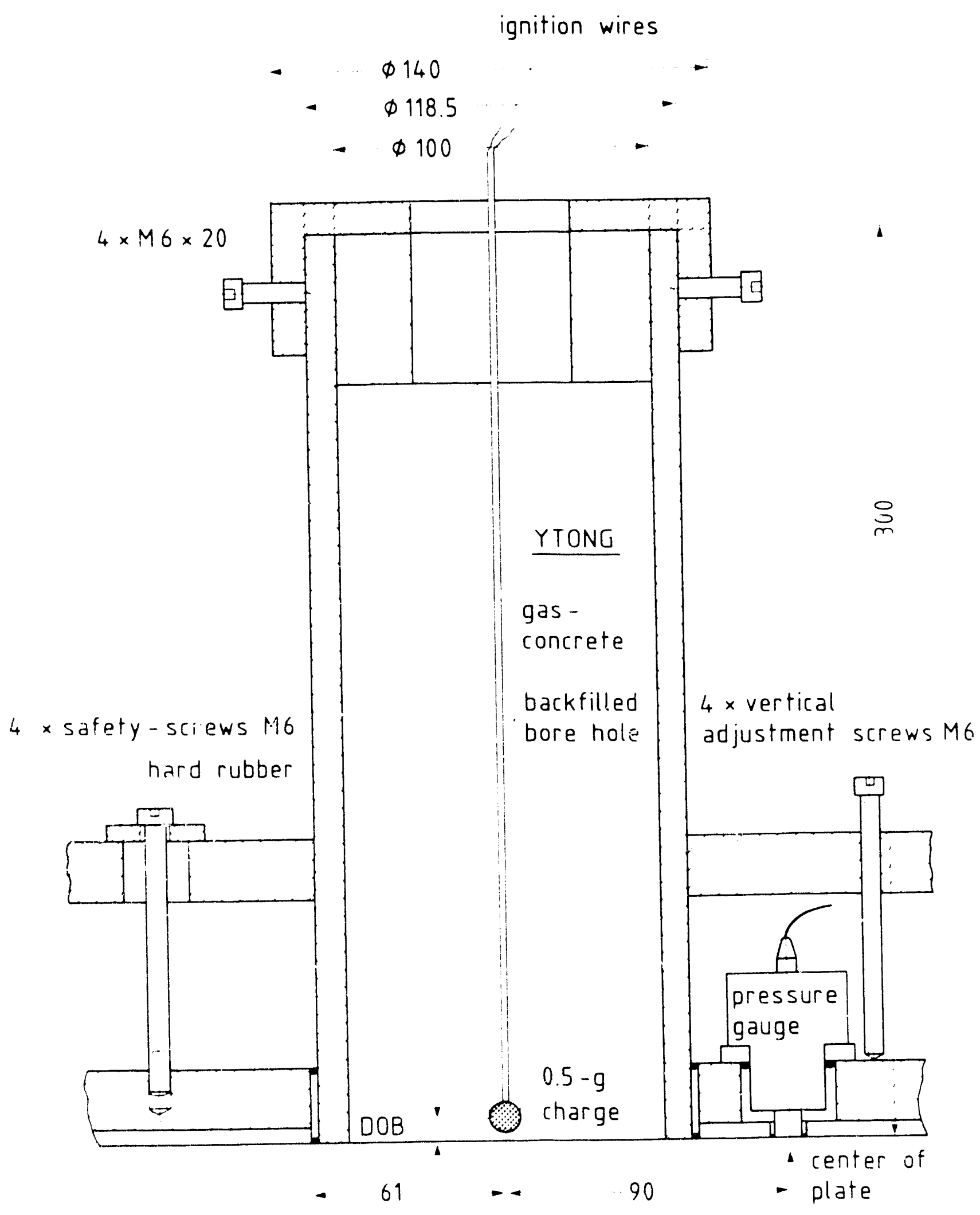

Figure 2. Installation of the $0.5 \mathrm{~g}$ charge into aerated grout and shock-isolated mounting of the ect-up into the explosion chamber. 


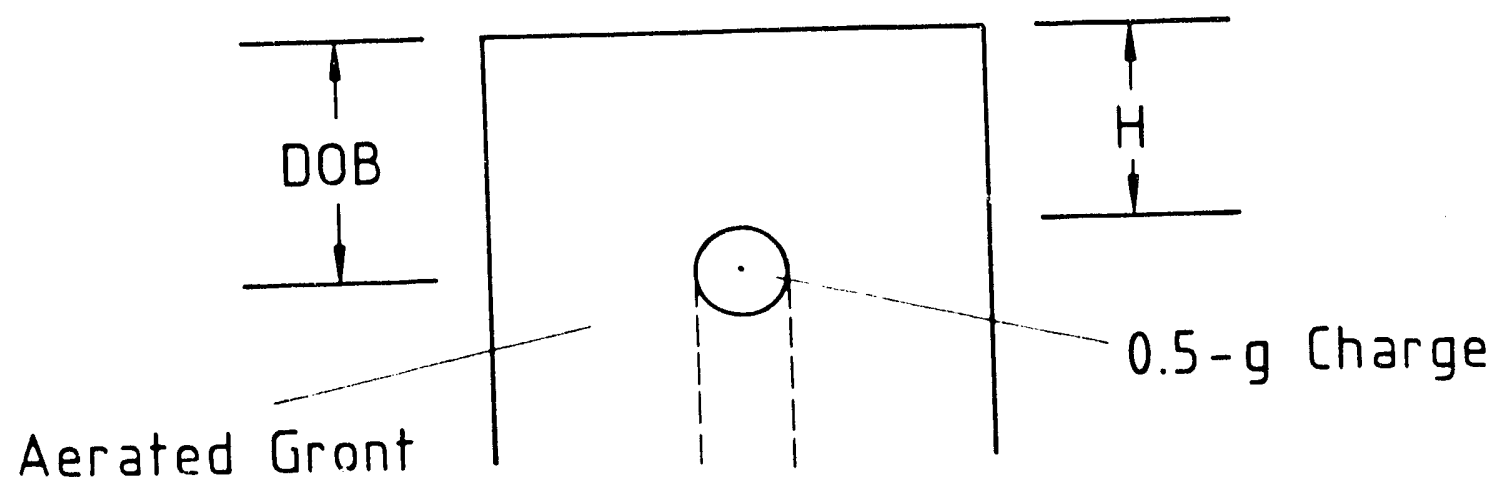

Figure 3. Definition of depth of burst, DOB, and overburden. $\mathrm{H}$.

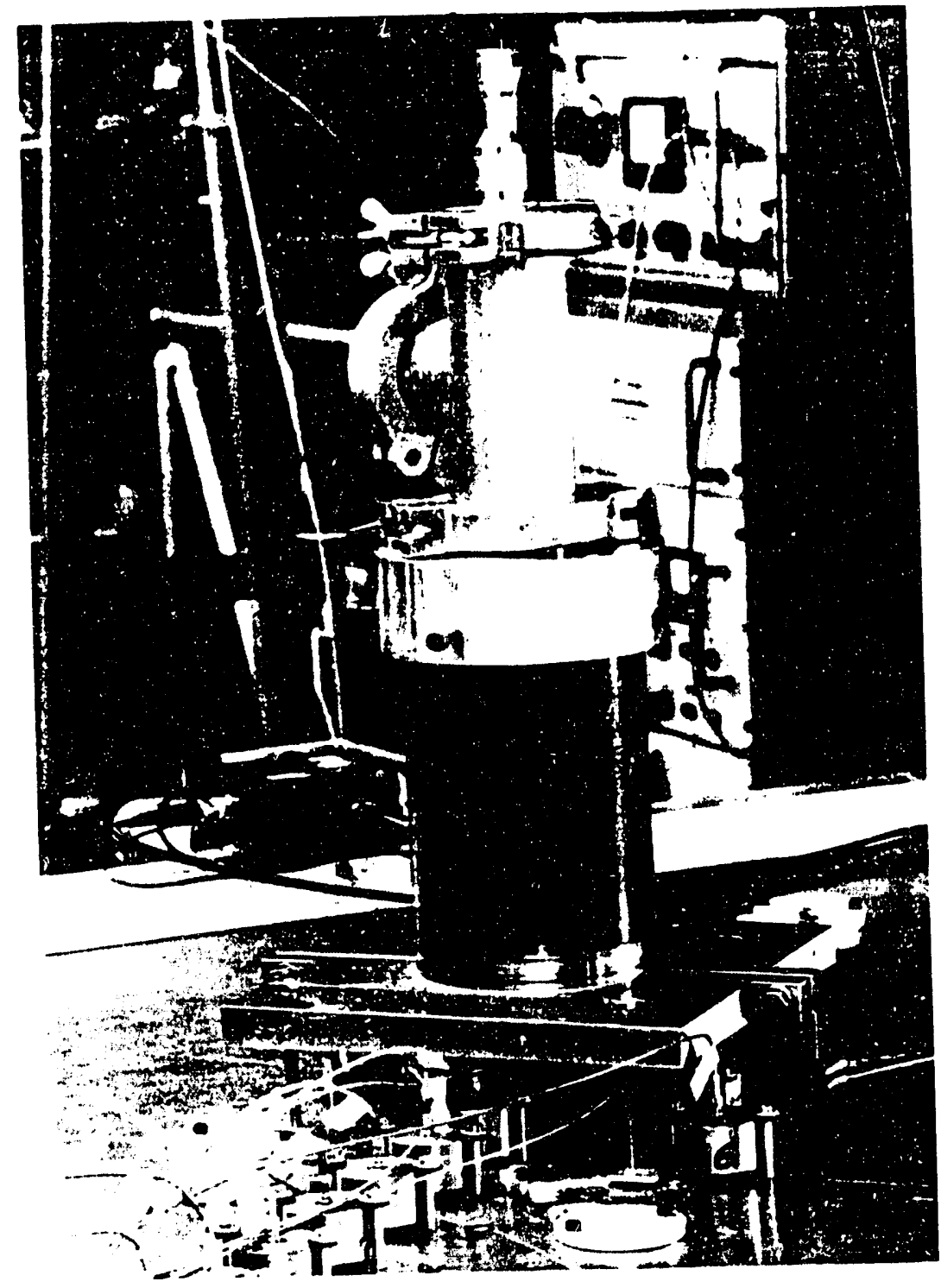

Figure 4. General view showing the construction of the YTONG holder. 


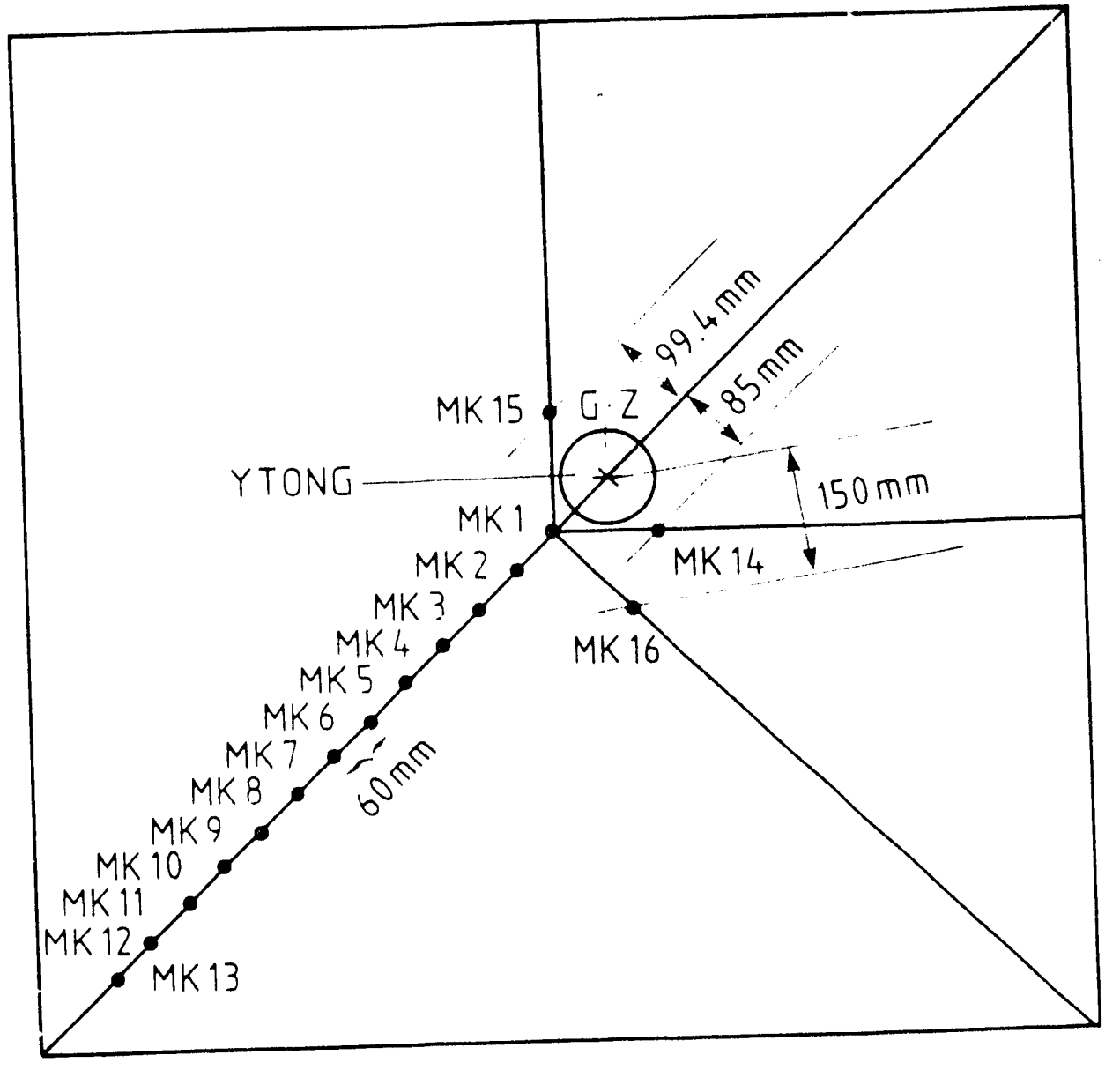

Figure 5. Position of the shock-isolated pressure gauges. MK1 - MK16.

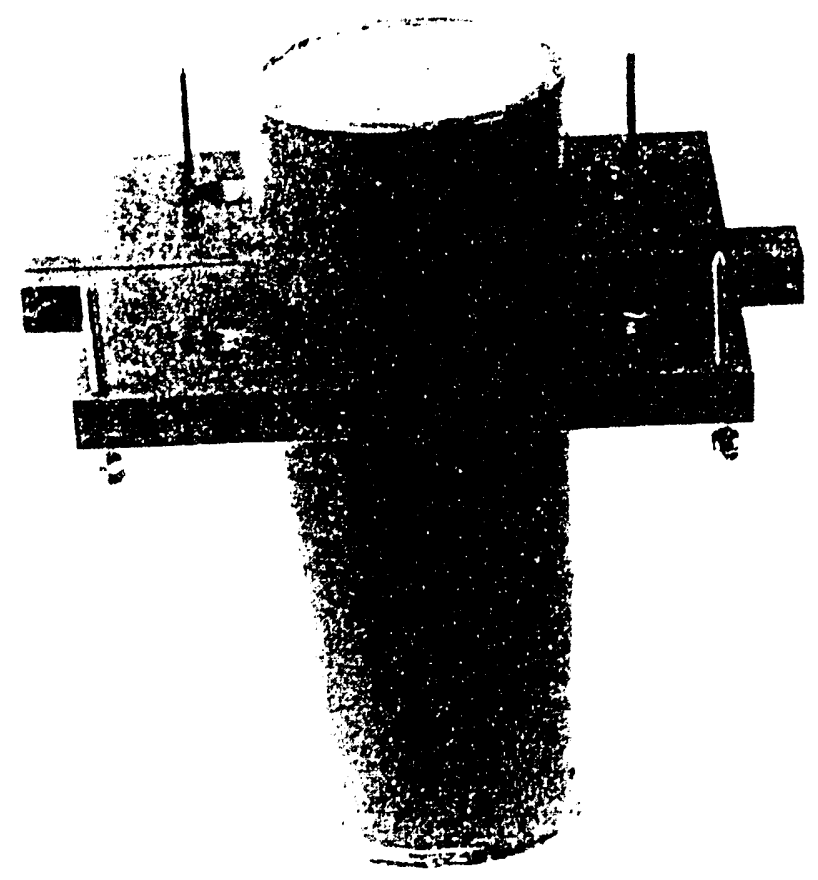

Figure 6. Aerated-grout specimen after test (still embedded in steel tube). 
CHARGE GEOMETRY

-

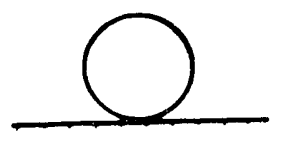

SURFACE TANGENT SFHERE

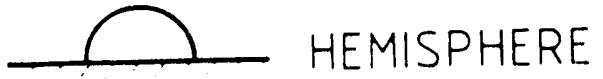

RADIUS DEPTH

1.0

1.0

0.61

$0.97 \quad 1.08$

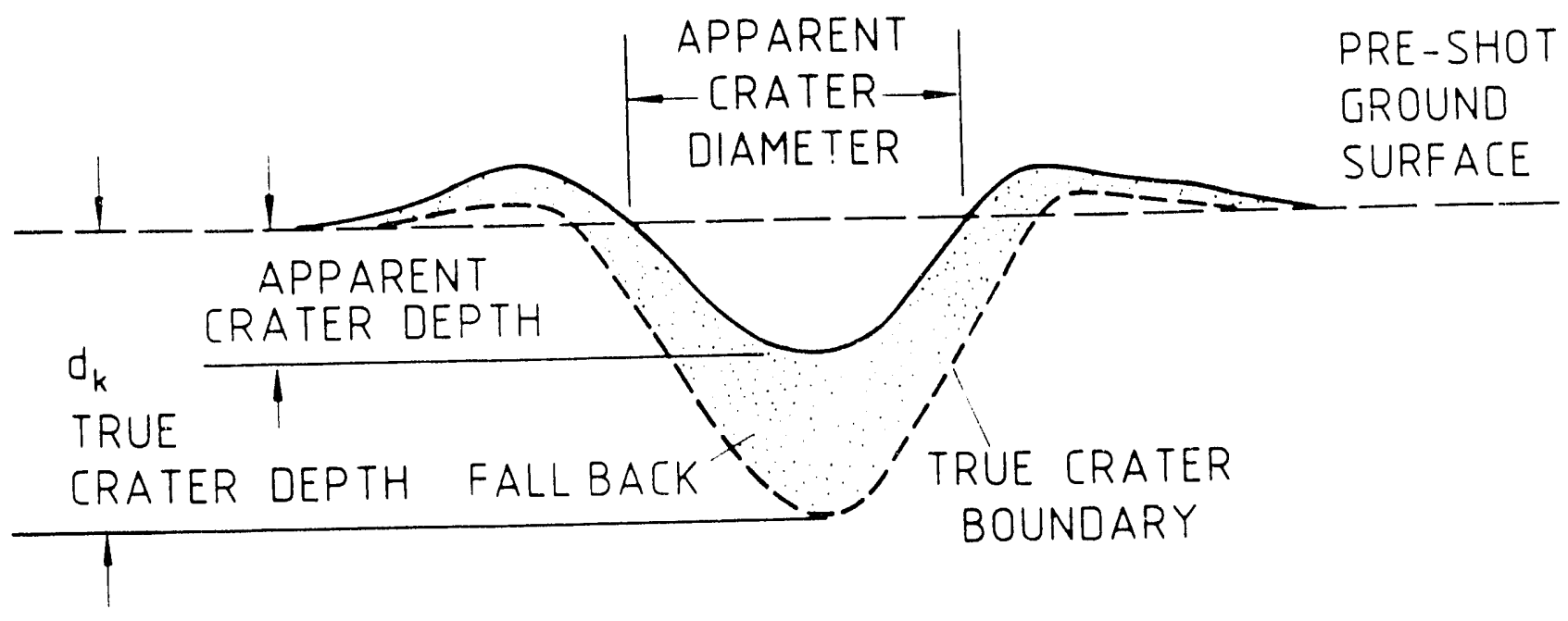

Figure 7. Apparent crater dimensions of different charge geometries and detimition of apparent and true crater depths. resp. 

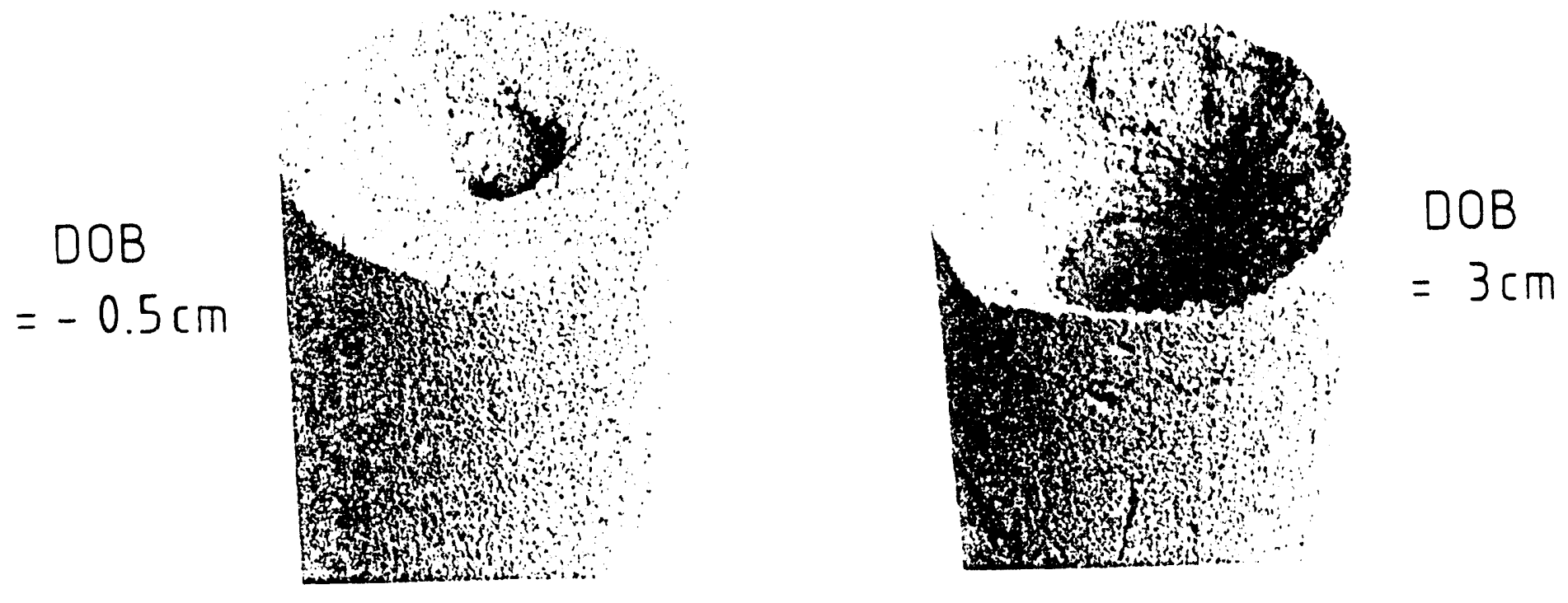

$=0 \mathrm{~cm}$
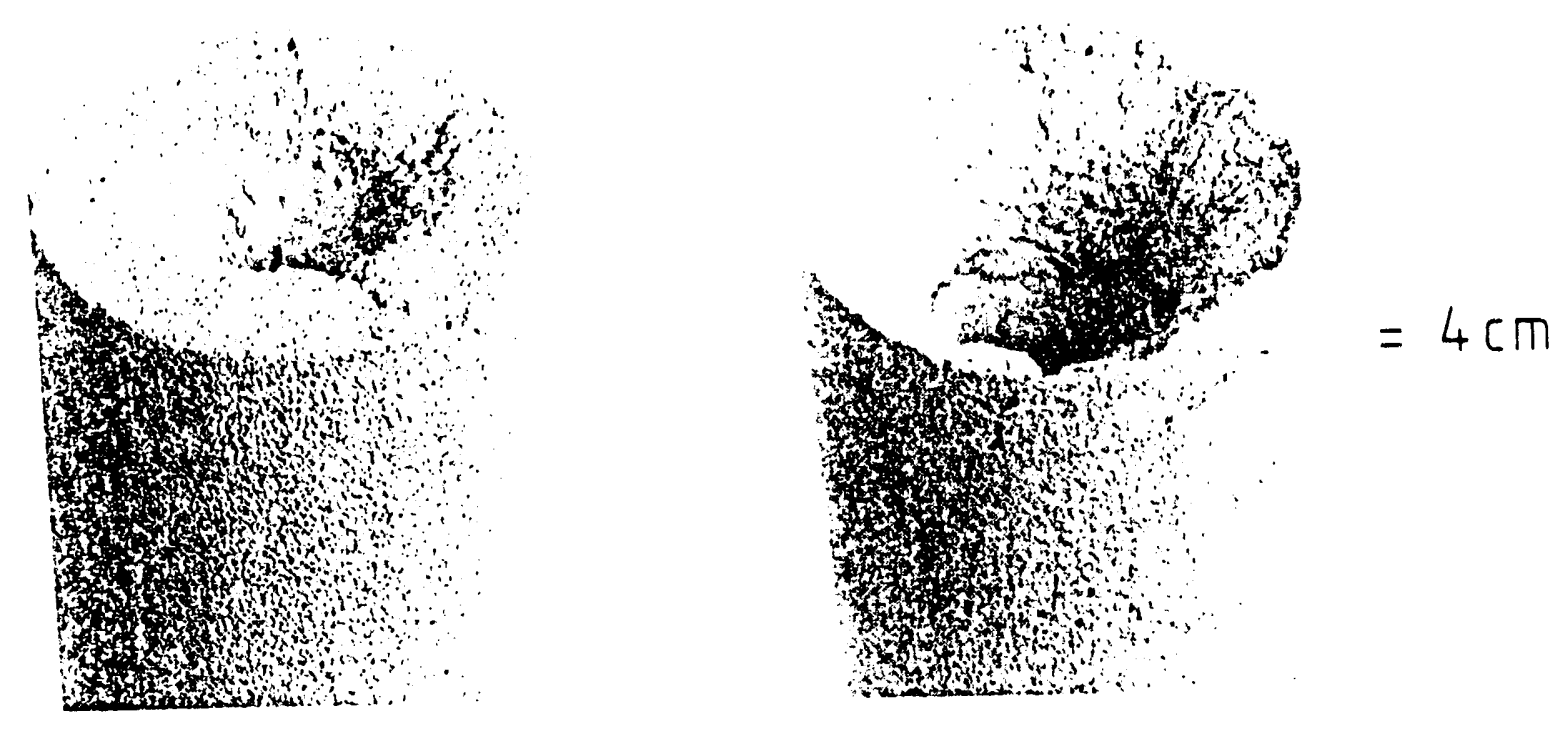

$=2 \mathrm{~cm}$
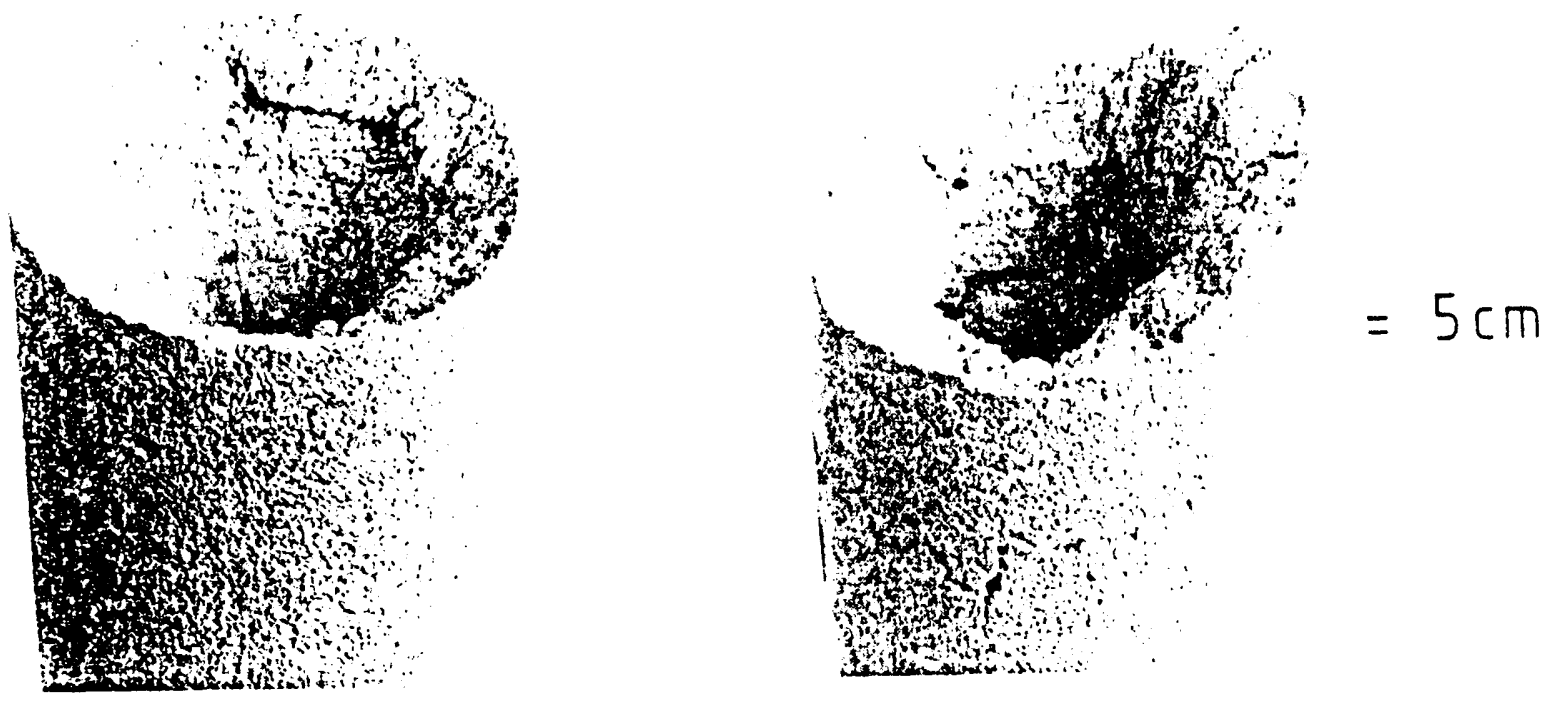

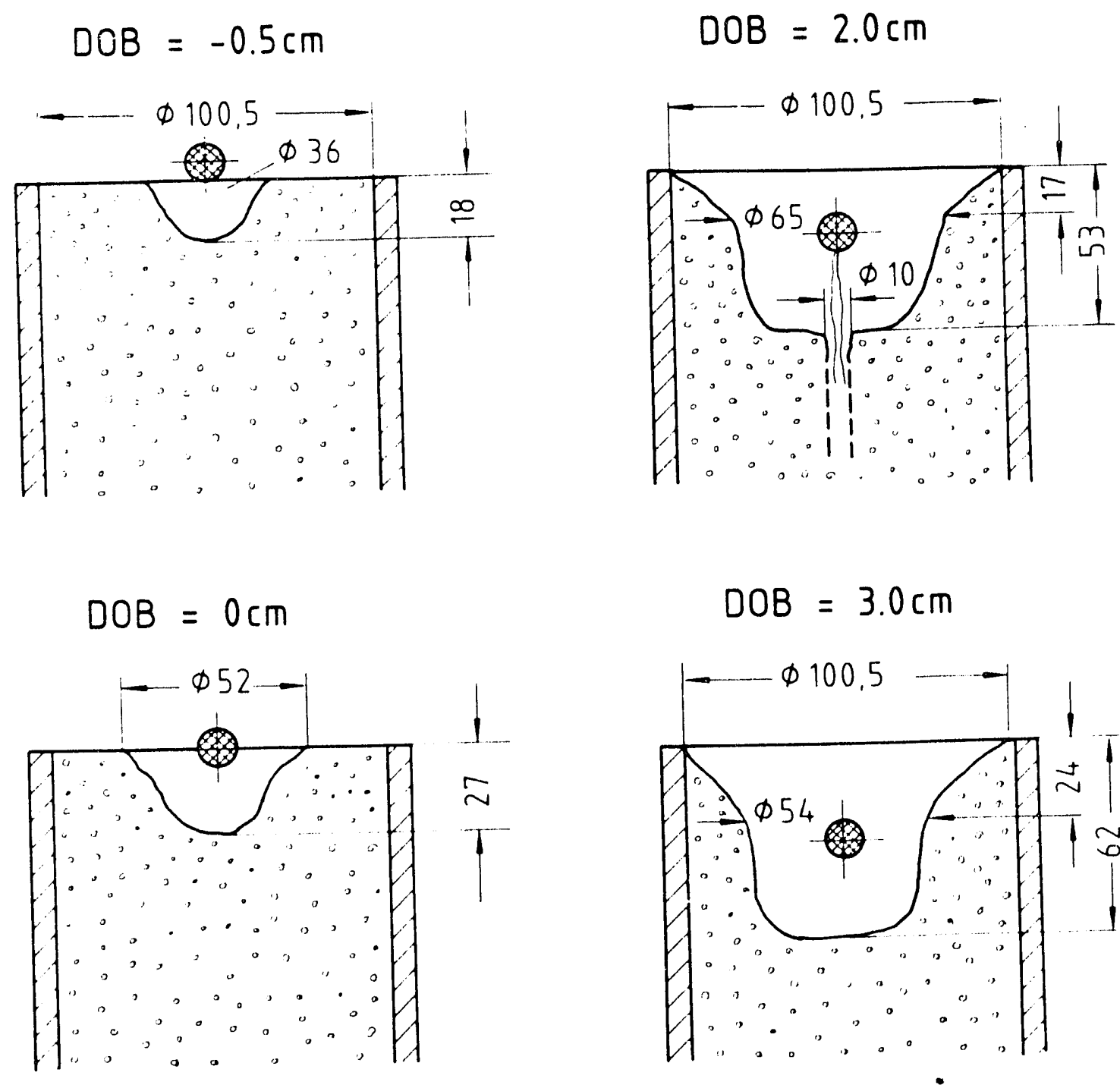

$$
D O B=3.0 \mathrm{~cm}
$$

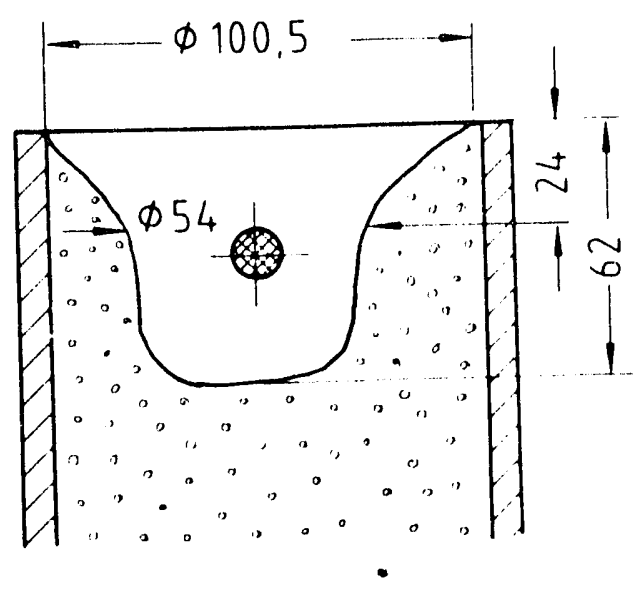

$D O B=1.0 \mathrm{~cm}$

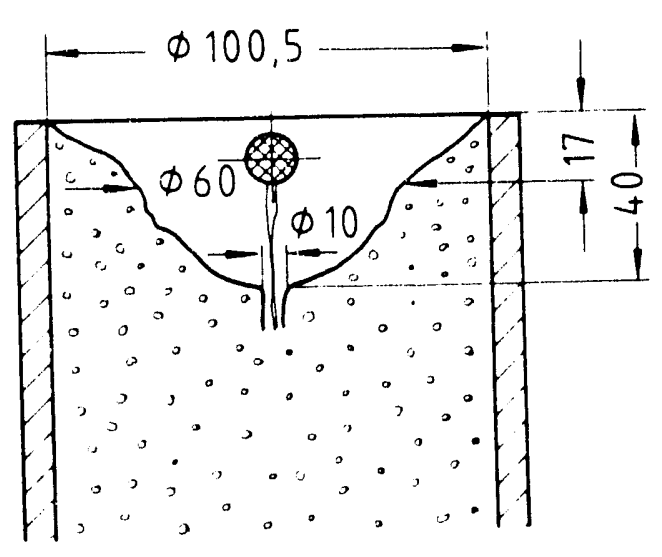

$$
D O B=4.0 \mathrm{~cm}
$$

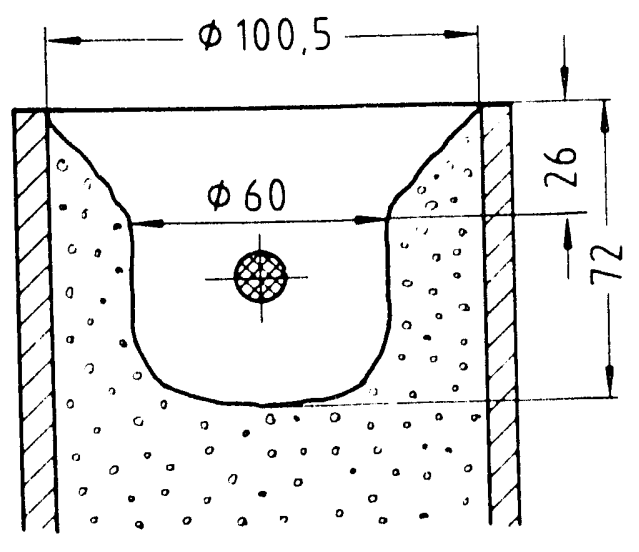

Figure 9. True crater contours. 


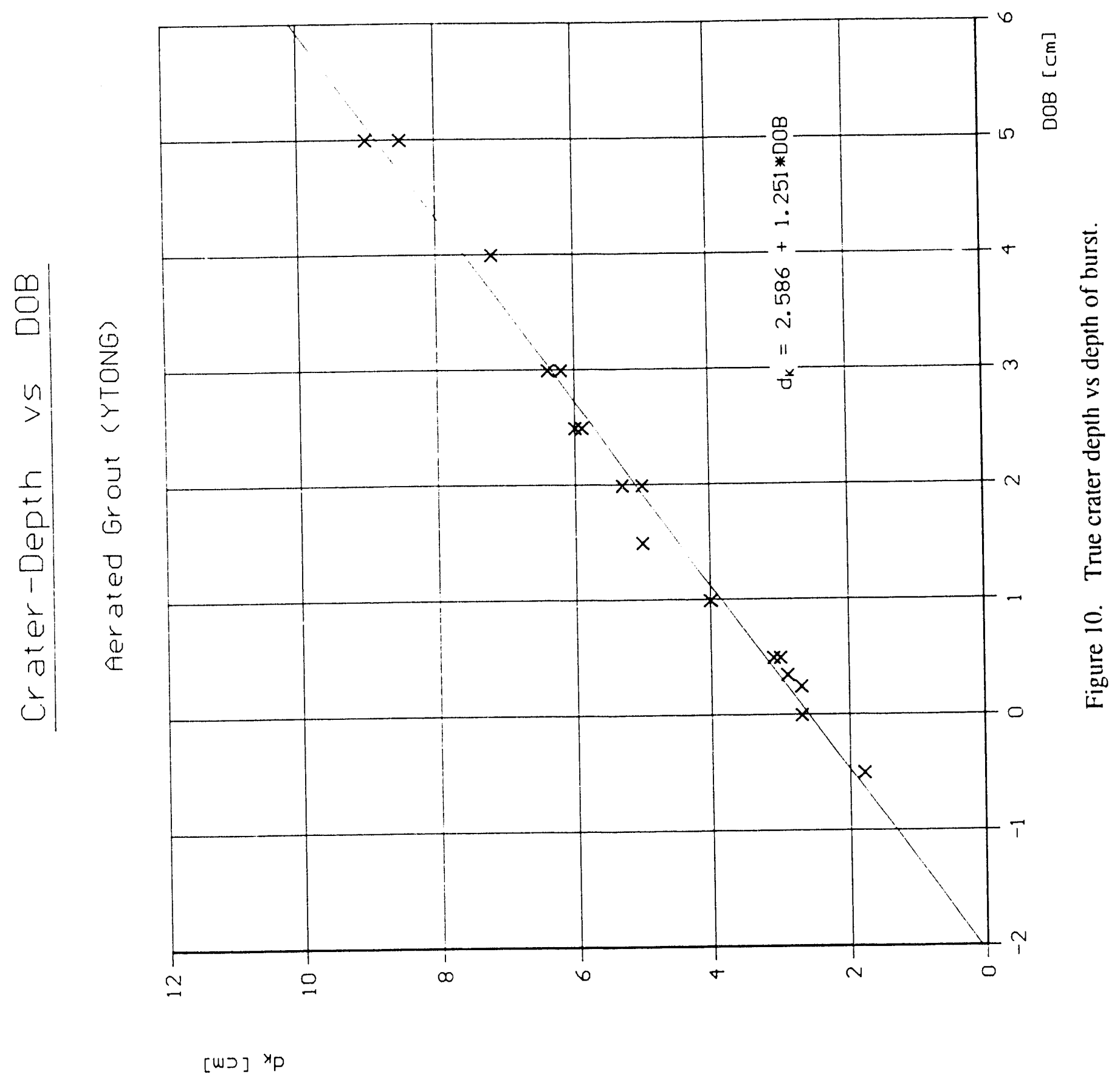




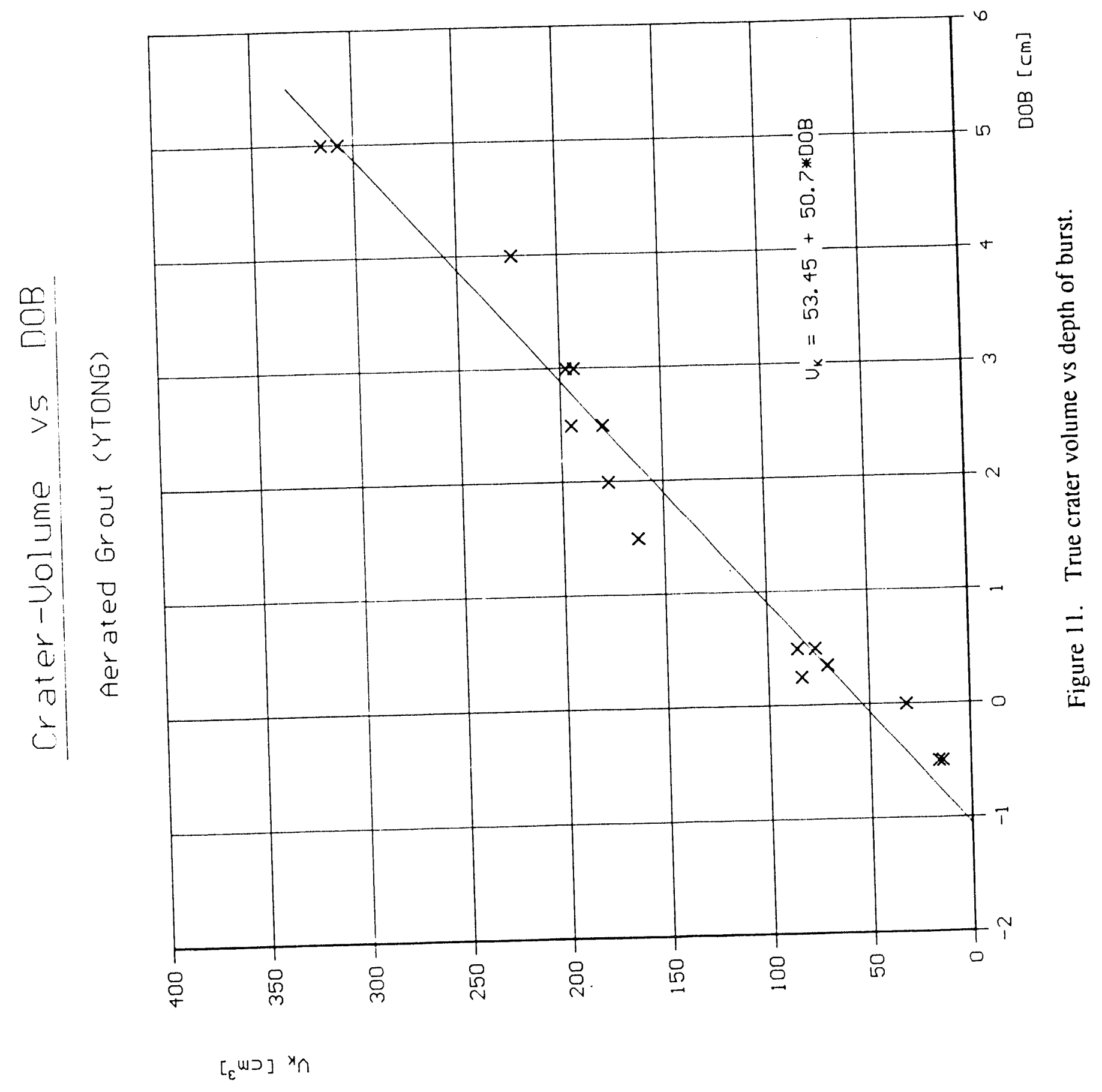


옴
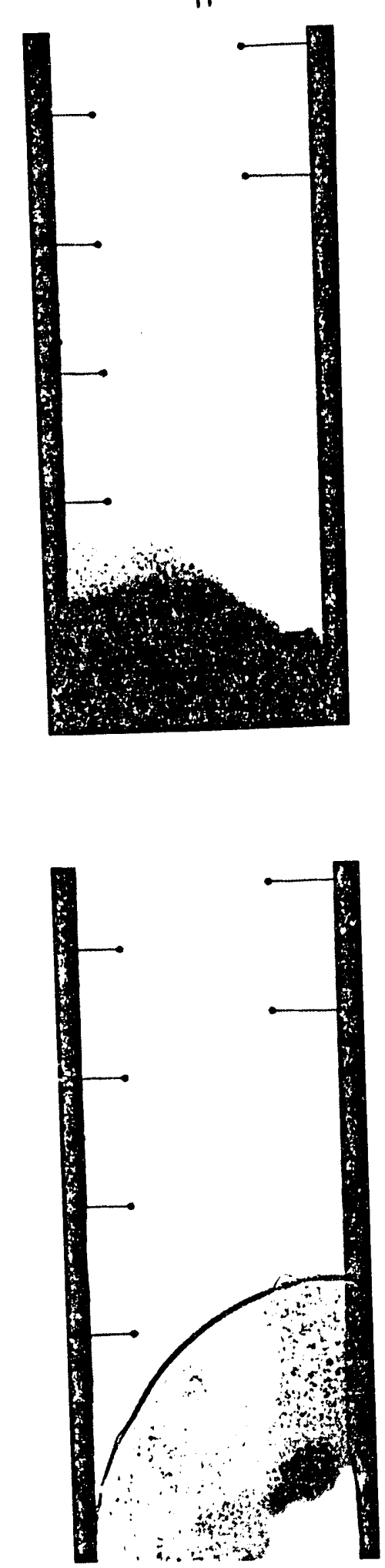

$$
\begin{array}{lc}
E \\
\varnothing & \tilde{U} \\
\square & 0 \\
1 \\
11
\end{array}
$$

$\underset{J}{E}$

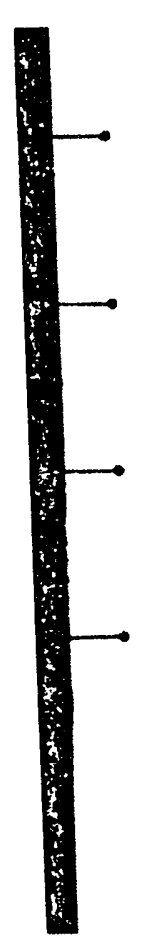

II
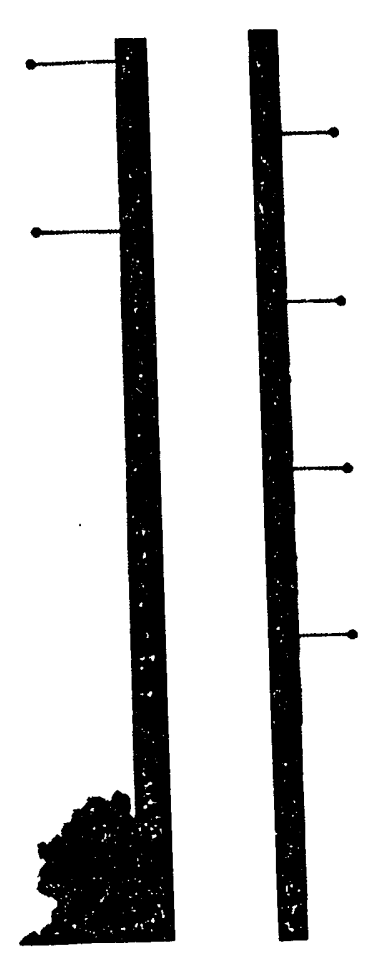

II

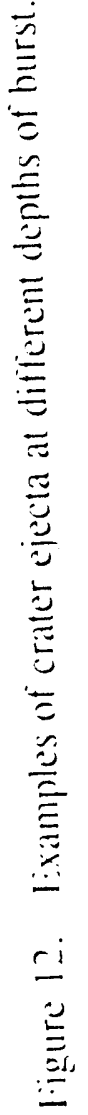




\section{TNT Spheres}

\section{Apparent Crater Depth vs Depth of Burst \\ (from DASIAC - TN - 86 - 15)}

- Scaled YTONG Data; NP-Spheres True Crater Depth vs DOB
First Order Approximation Last Square Fit

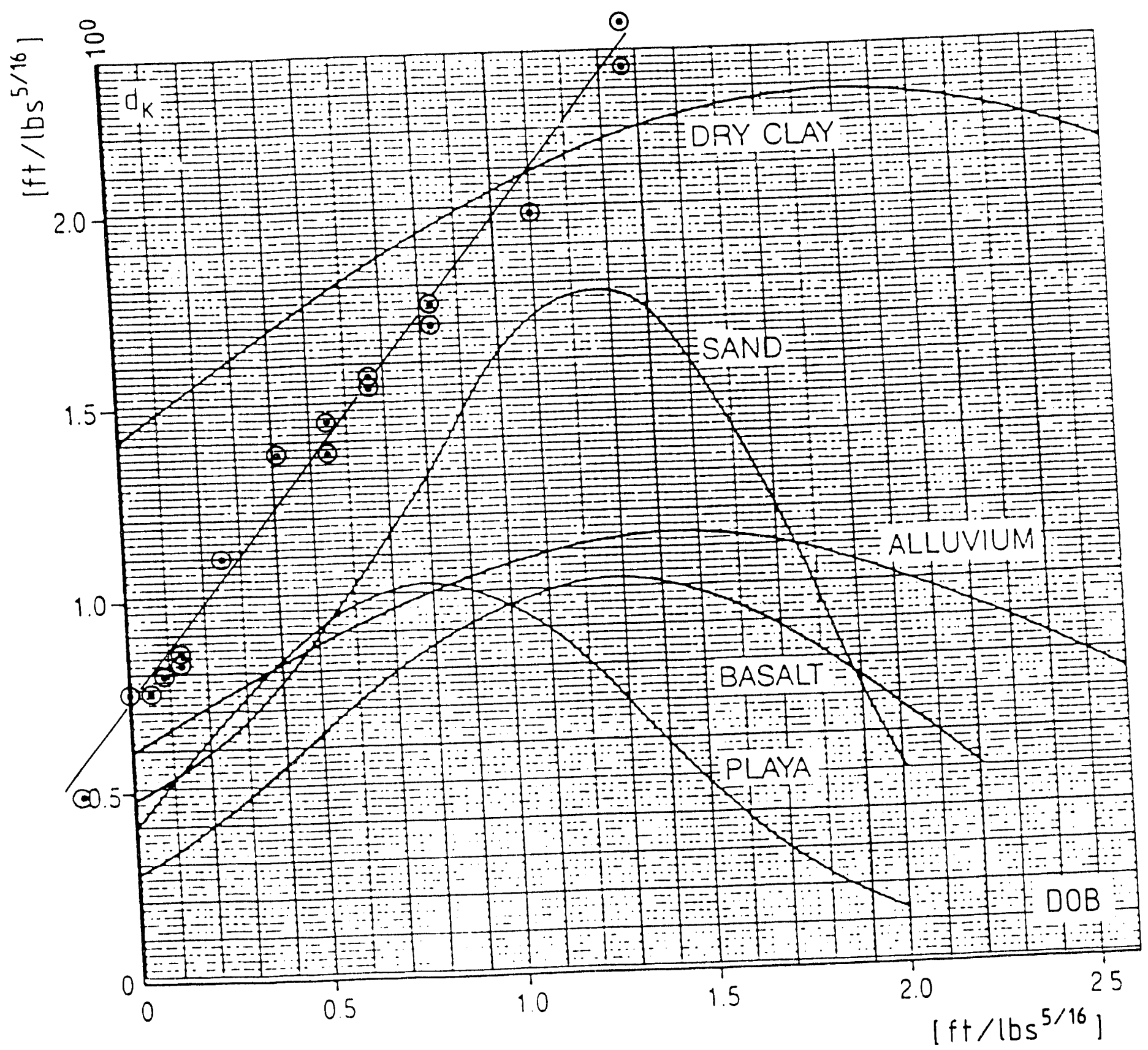

Figure 13. Comparison of YTONG crater depth with other soil naterial [3] 

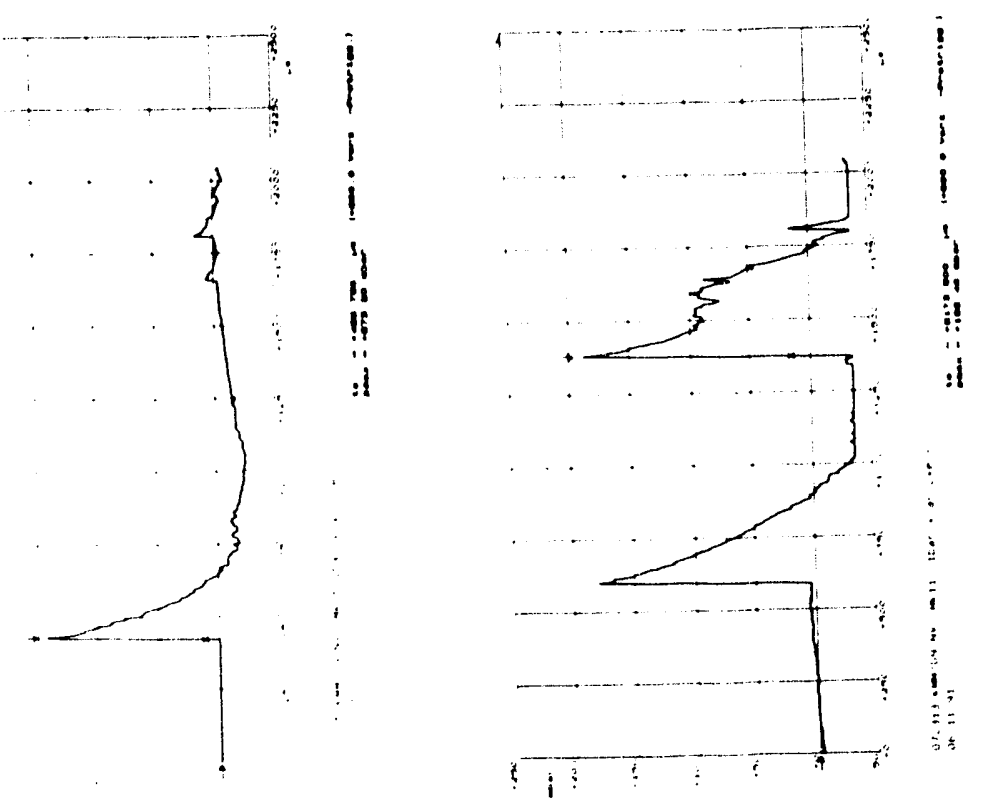

$\frac{1}{2}$
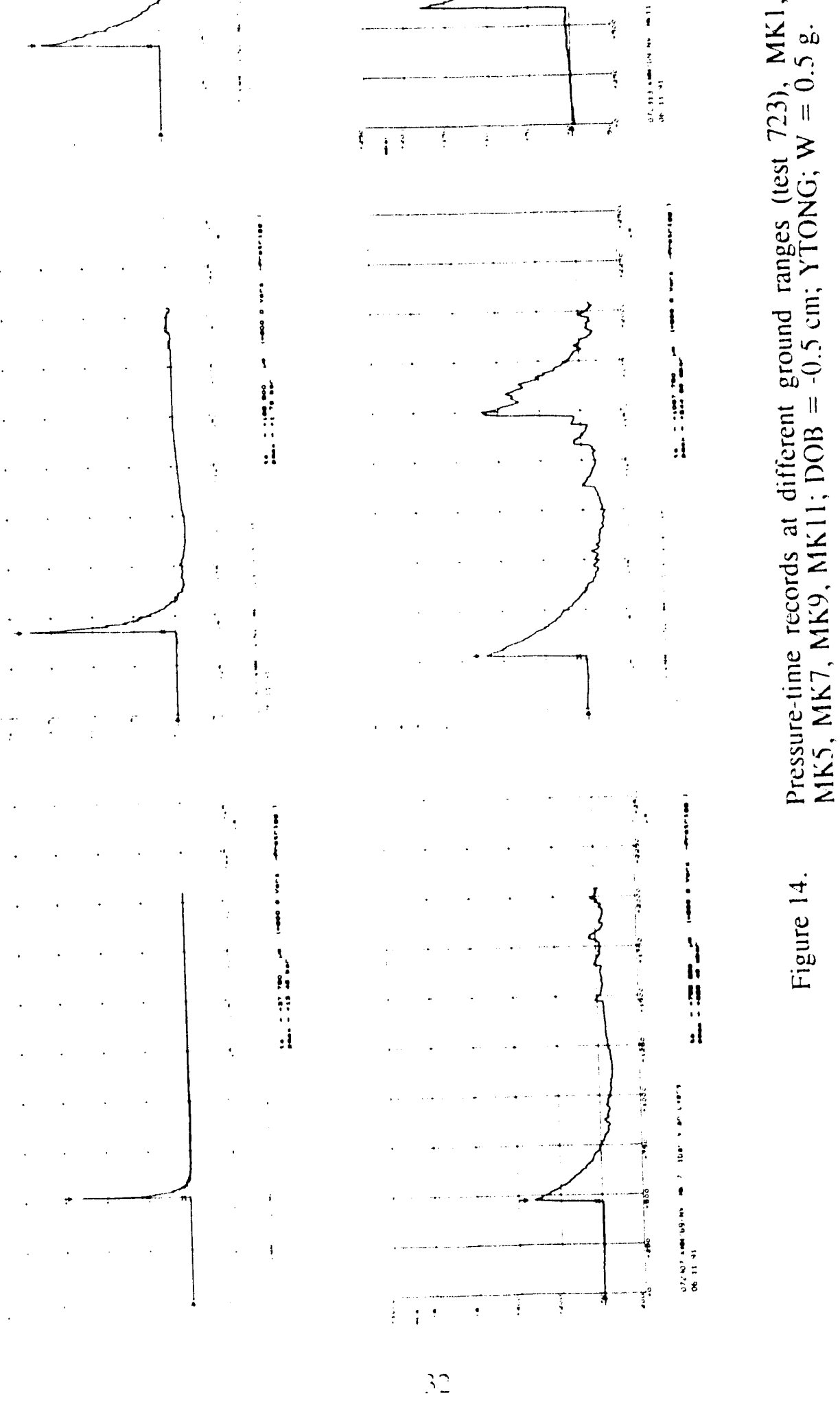


$$
\begin{aligned}
& \left\{\begin{array}{l}
3 \\
4 !
\end{array}\right. \\
& \{!
\end{aligned}
$$



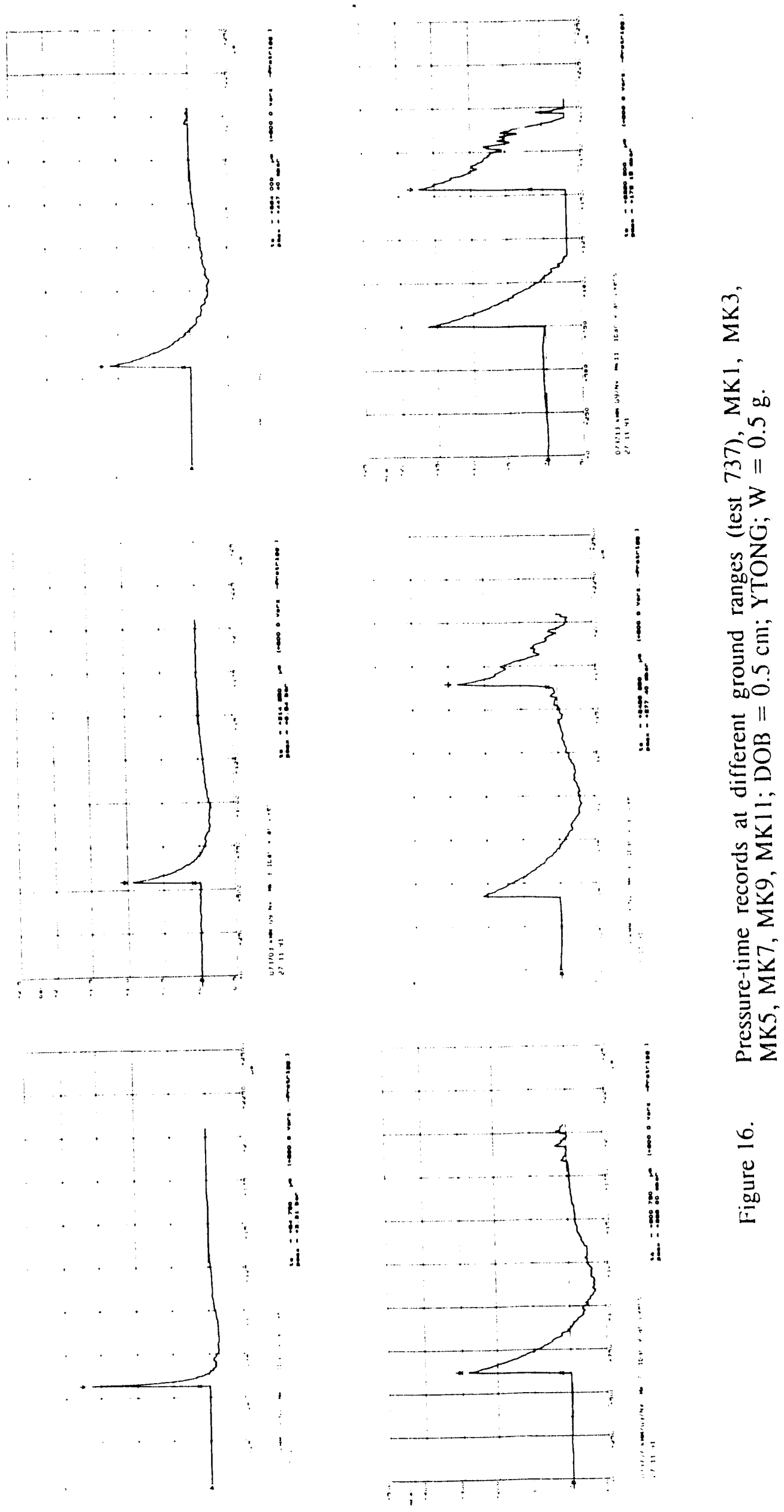

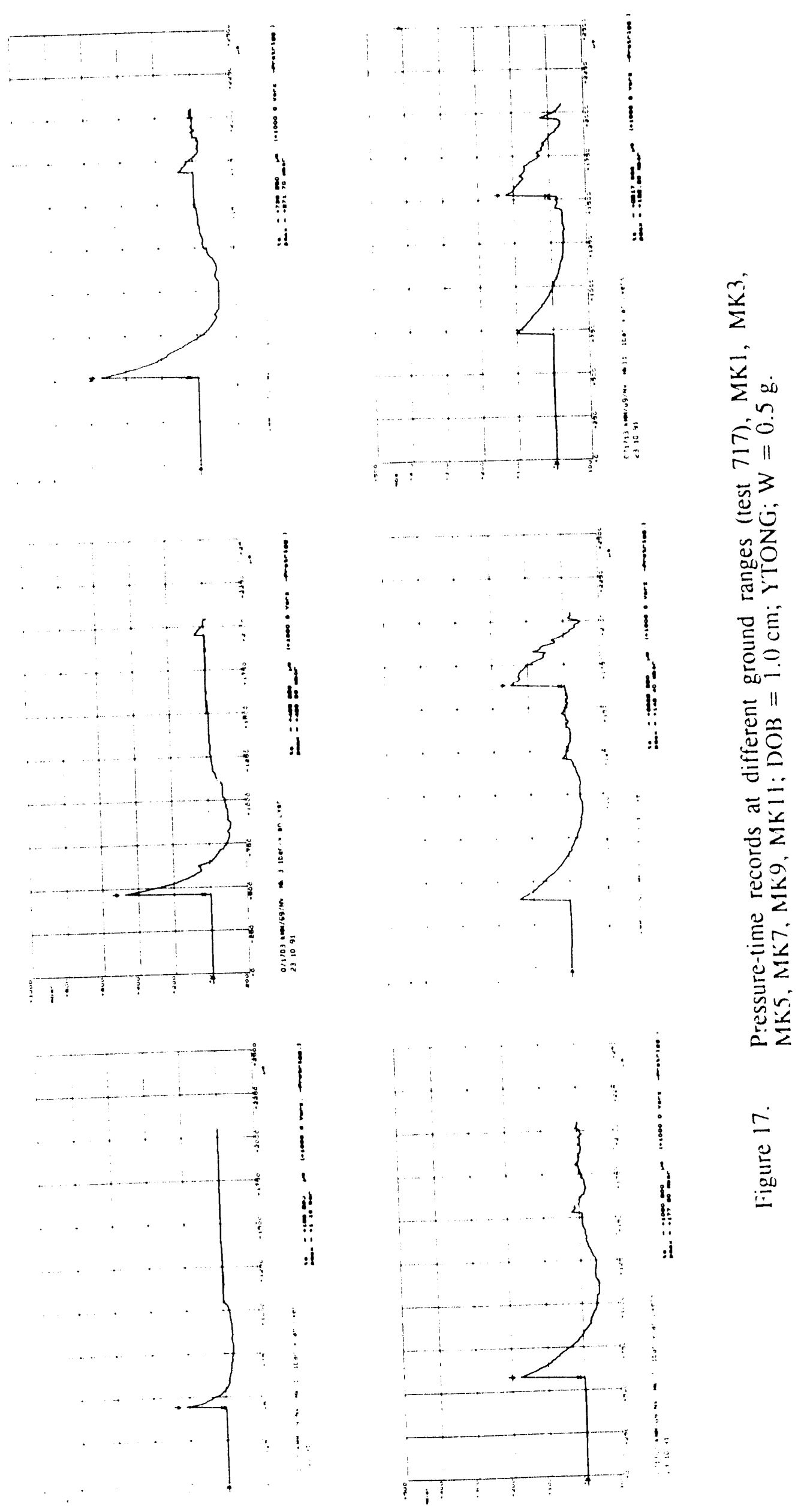

紊 


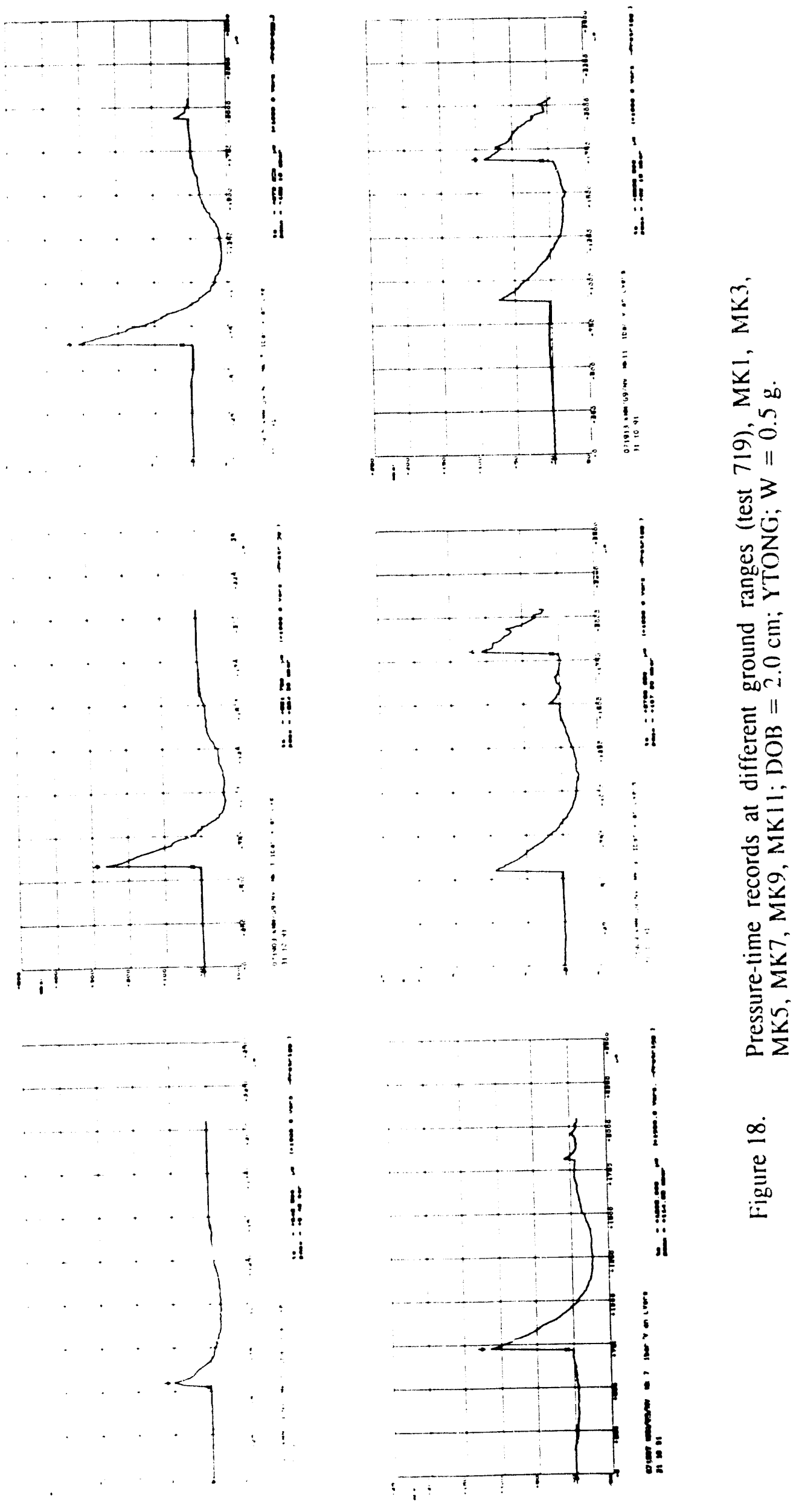



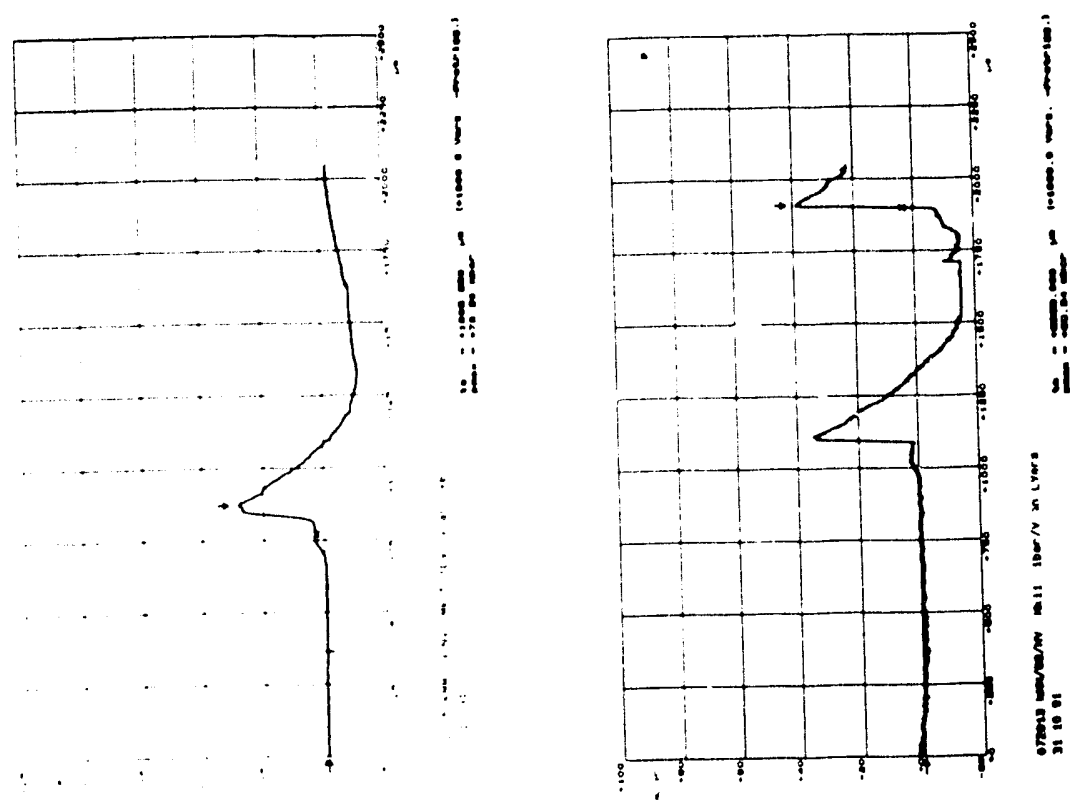

$\sum$
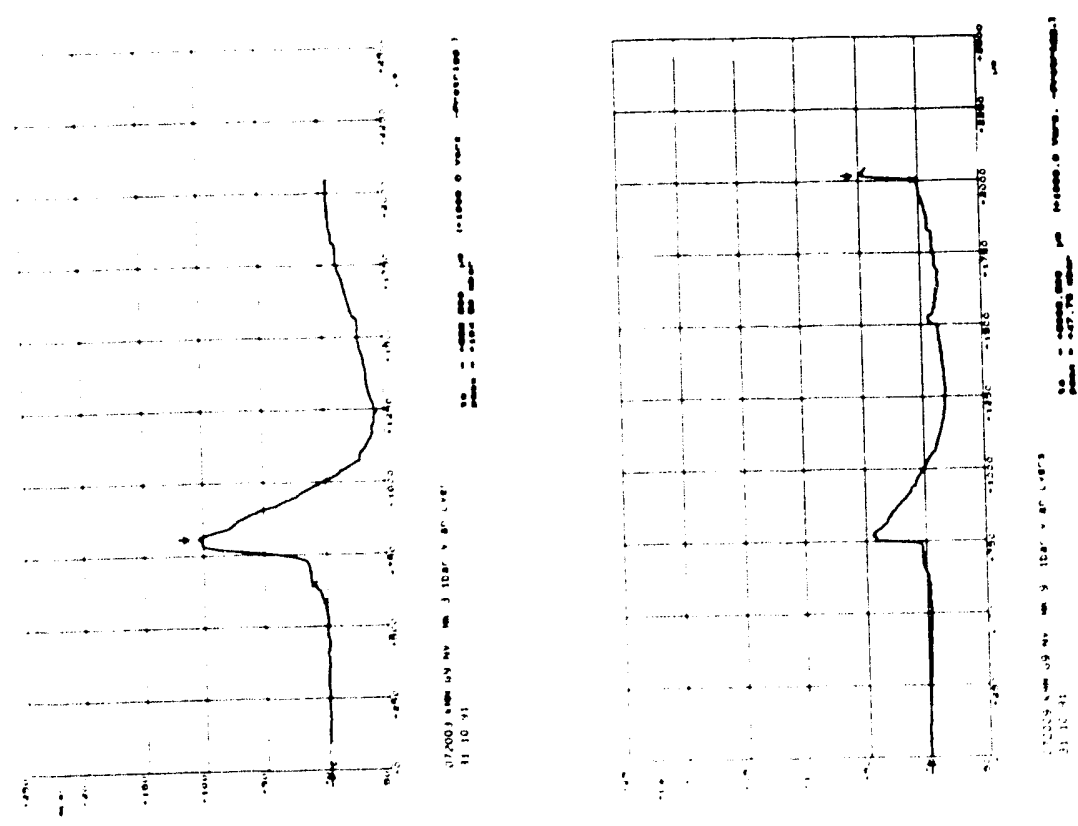

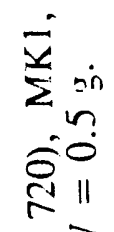

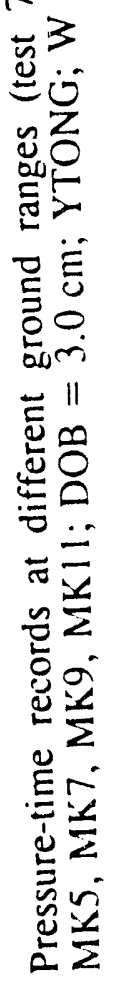
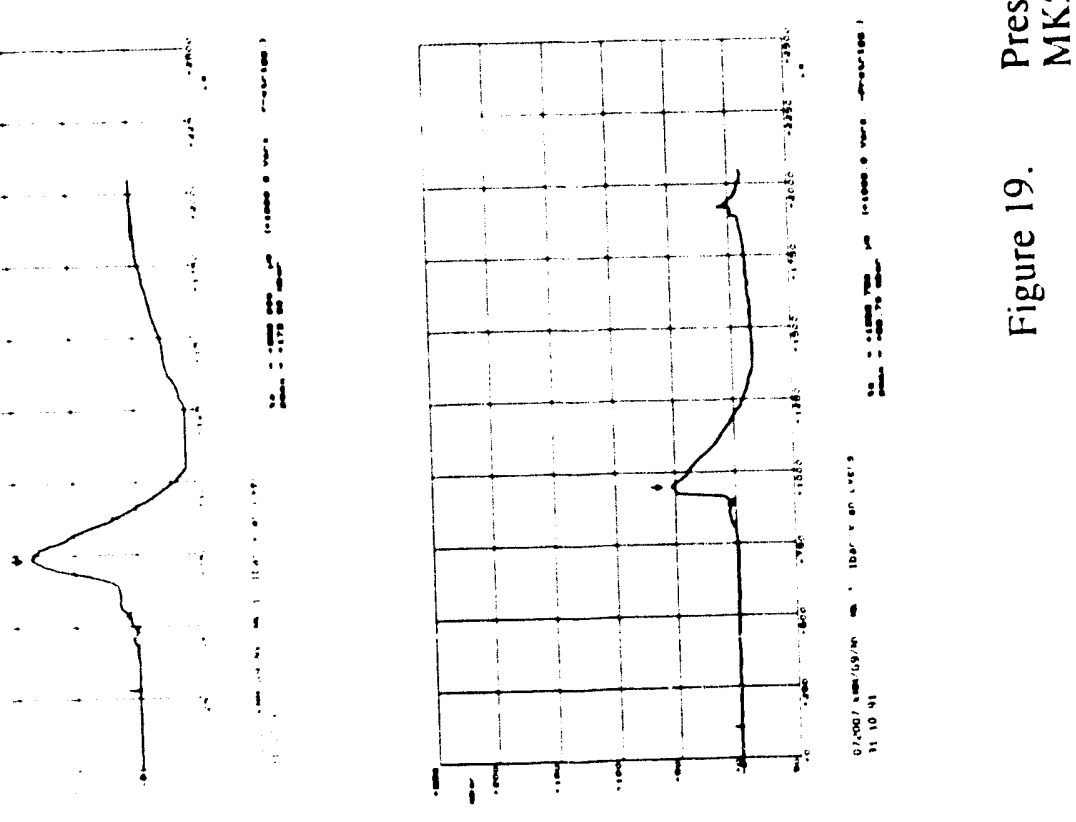

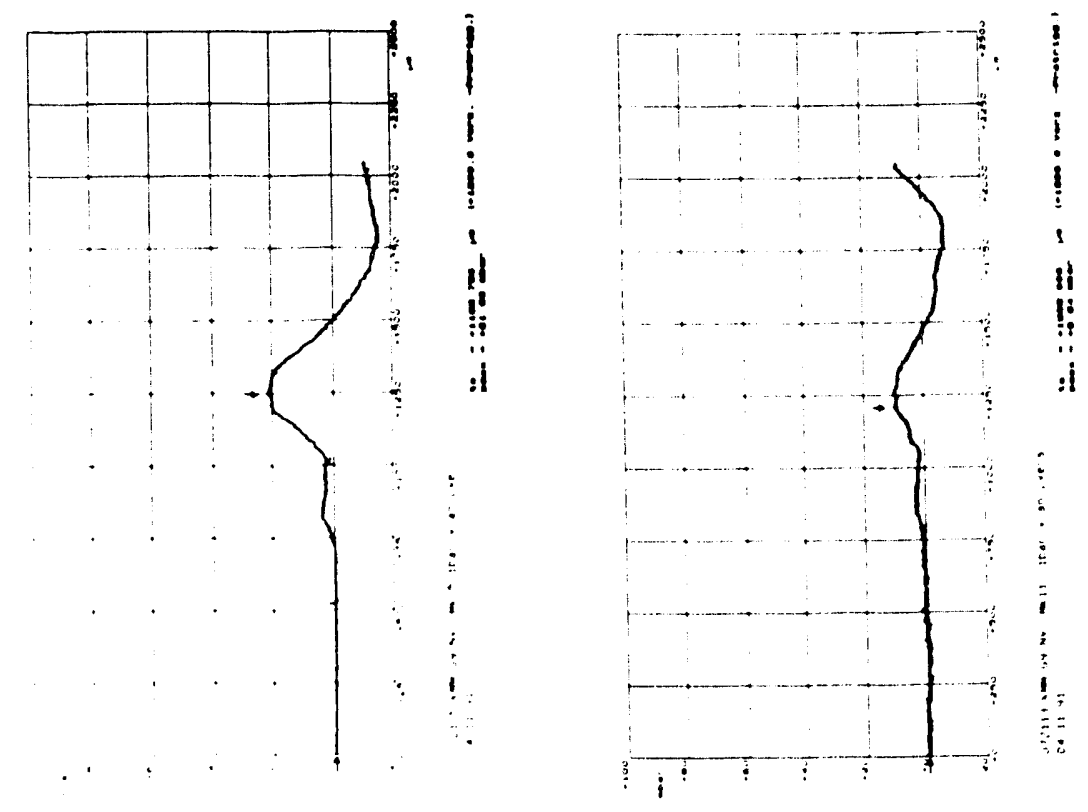

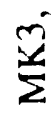
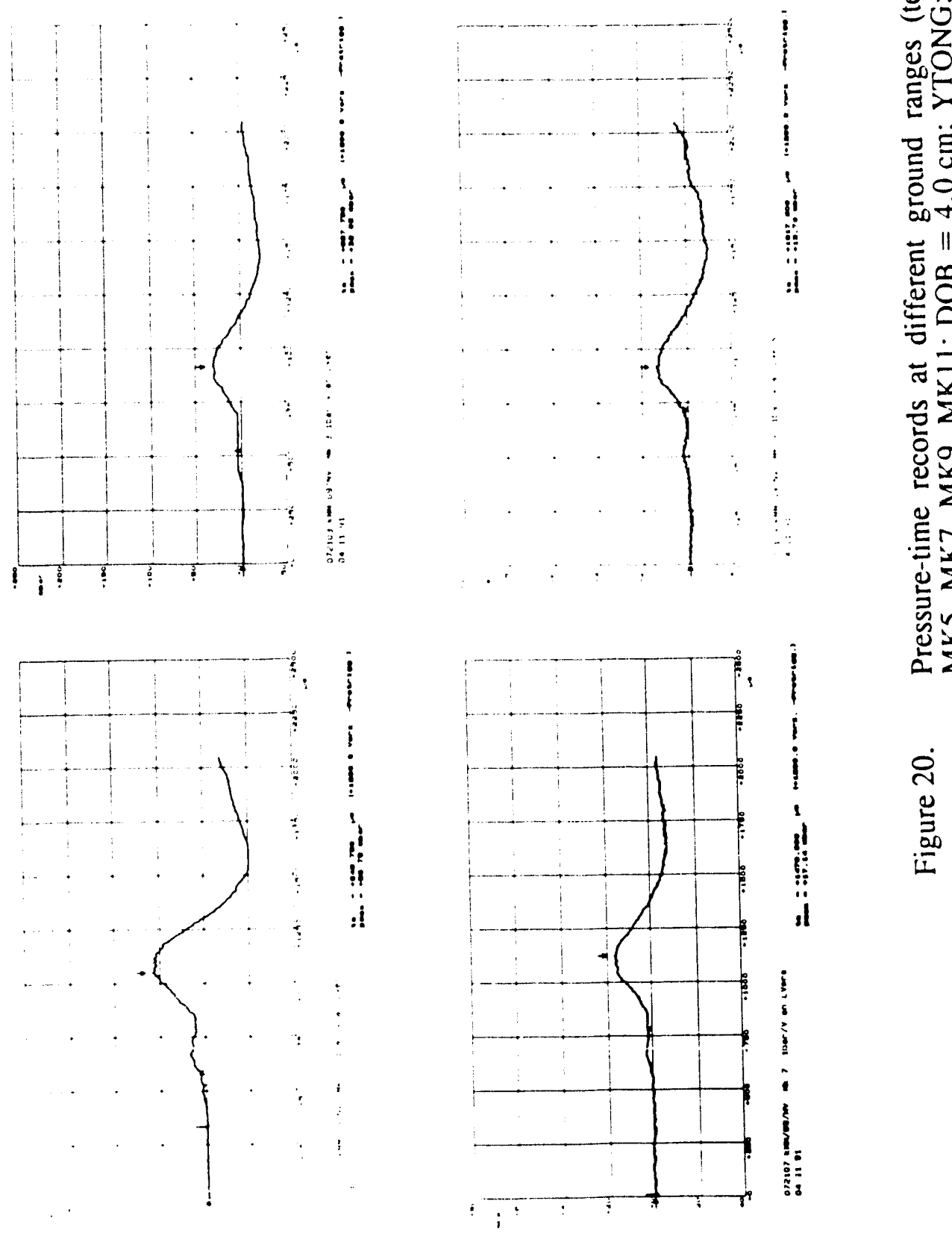


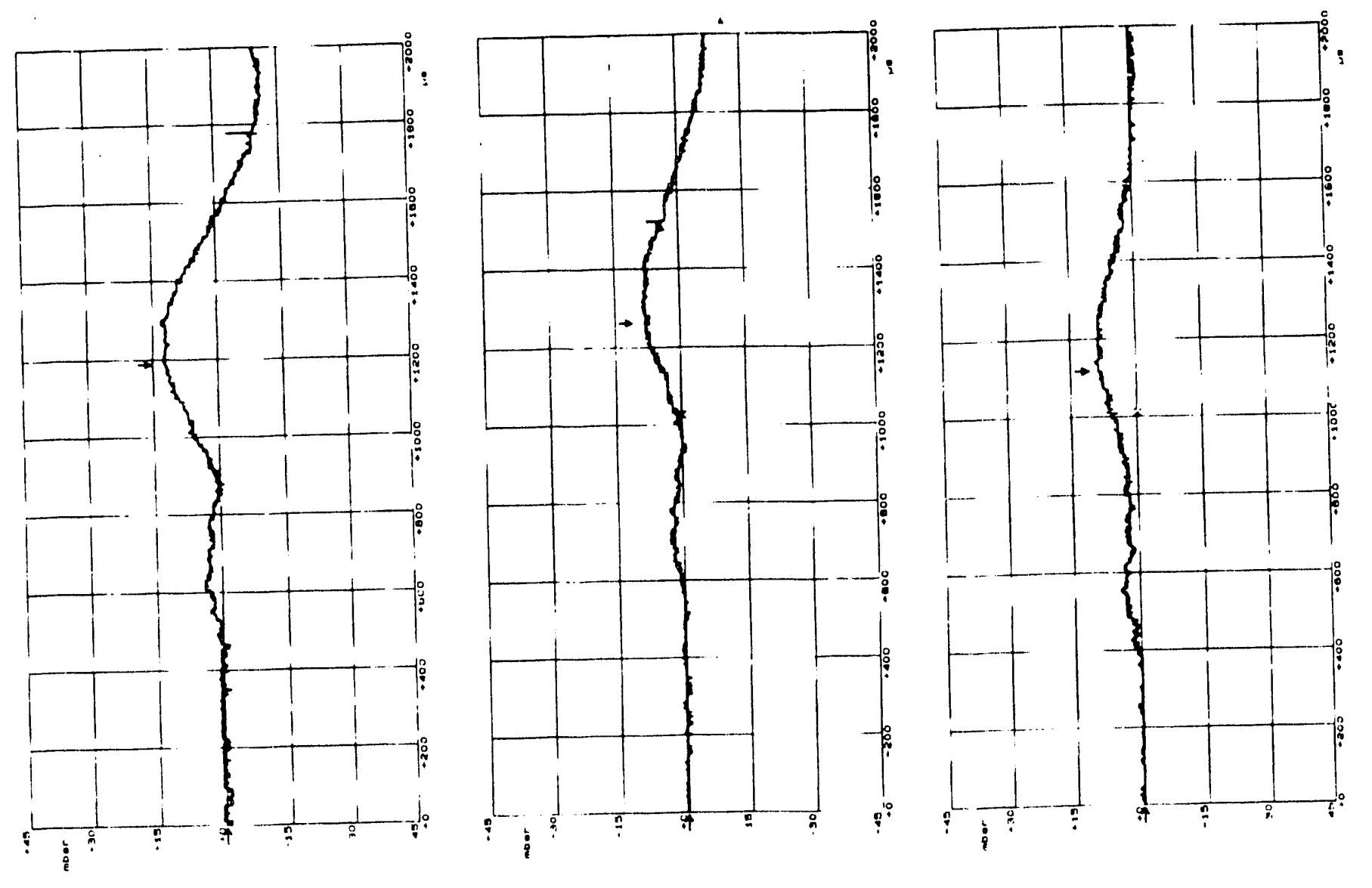

$\sum$ 

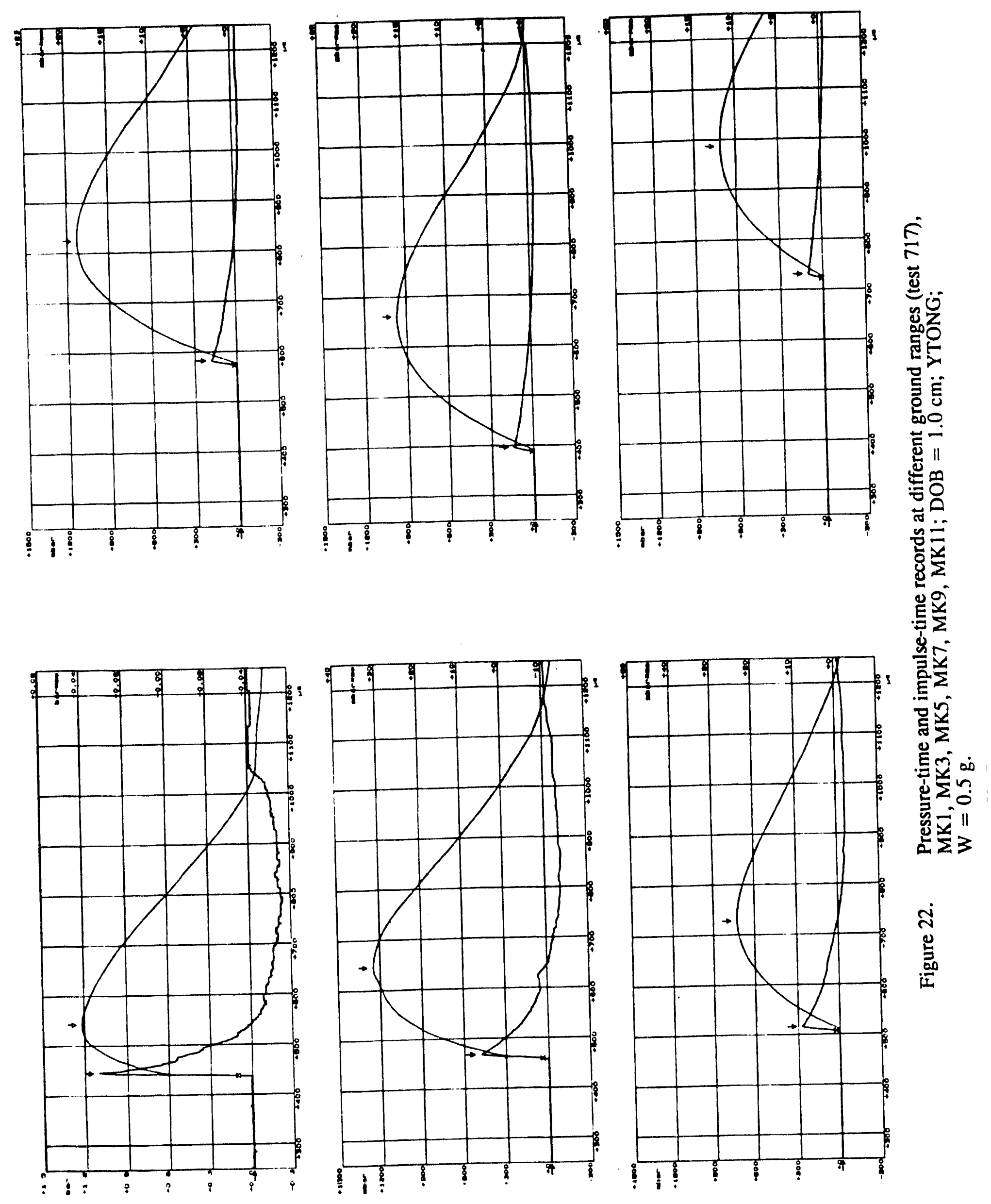

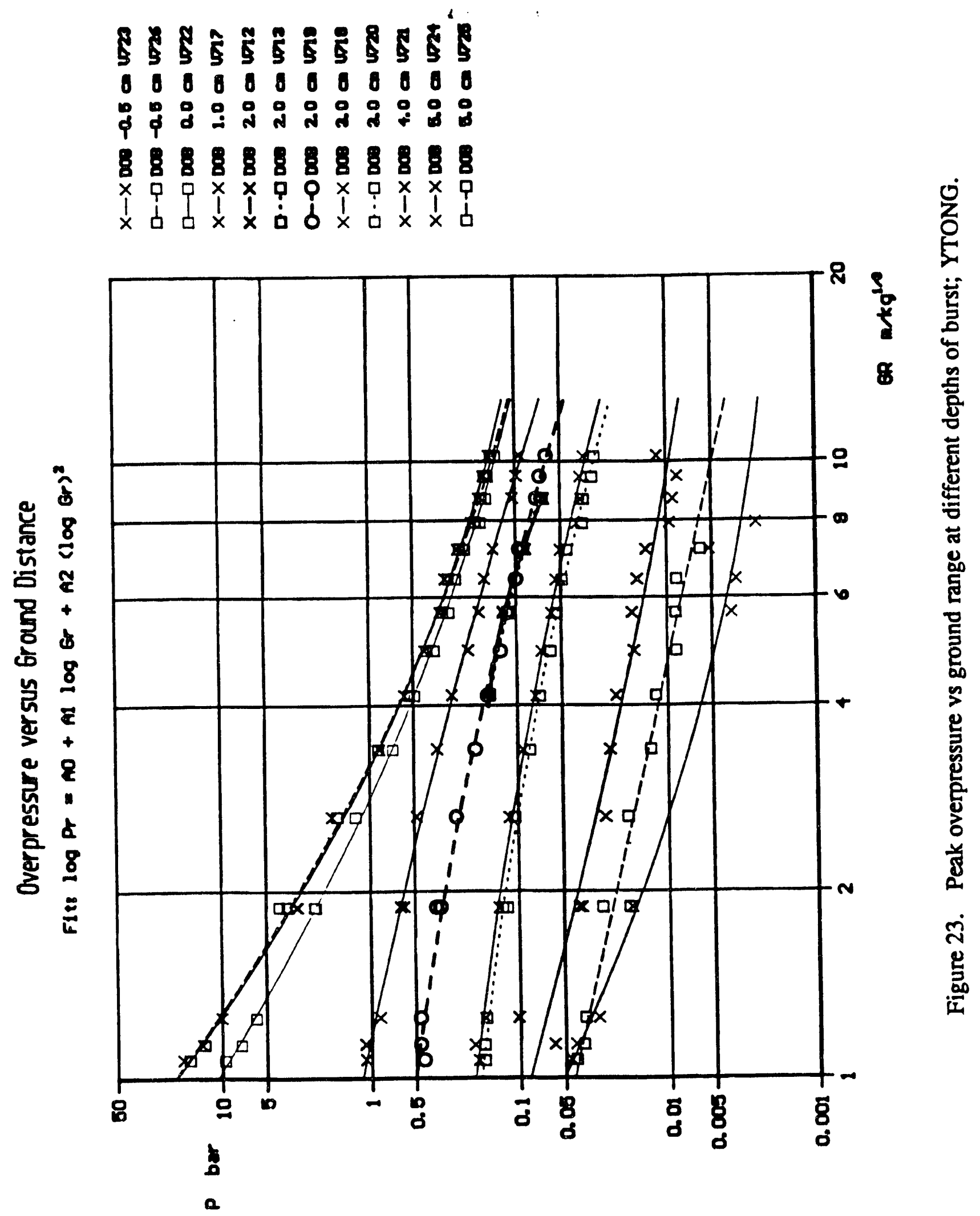
$\pm \pm \pm \pm \pm t \pm \pm t \pm t$

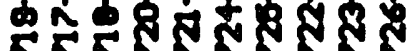

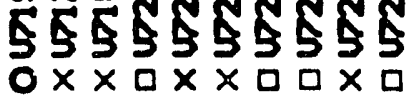

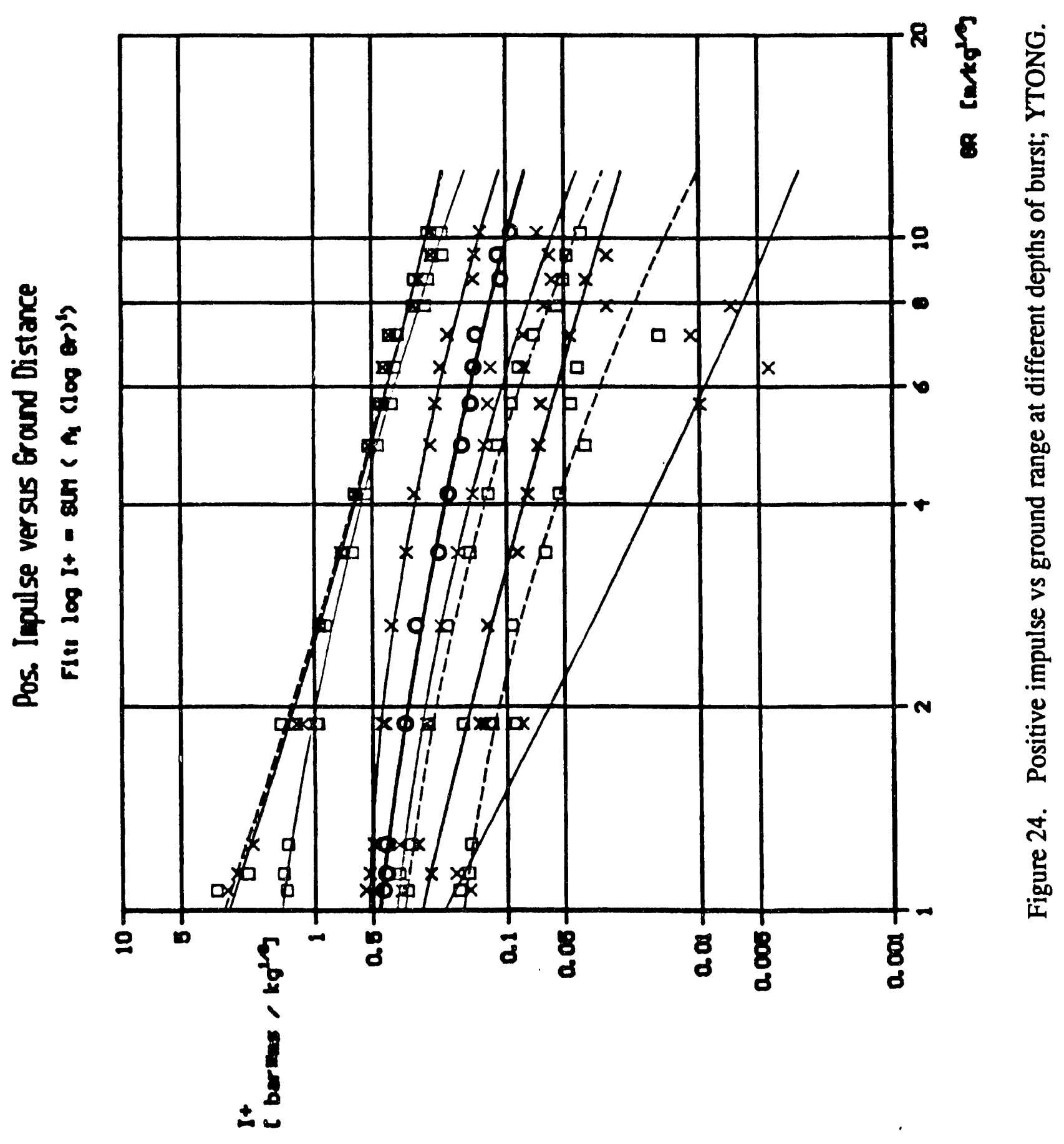




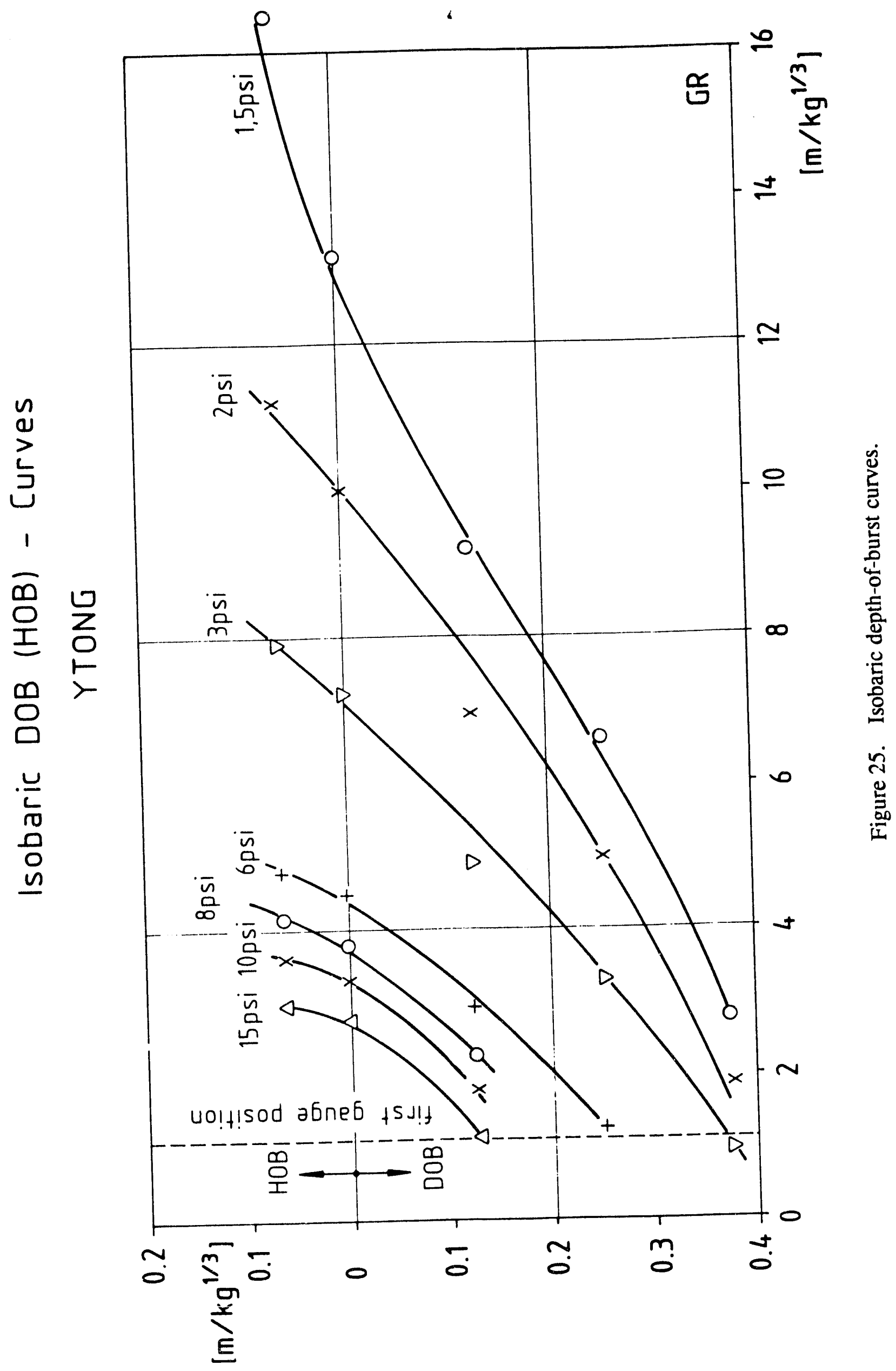




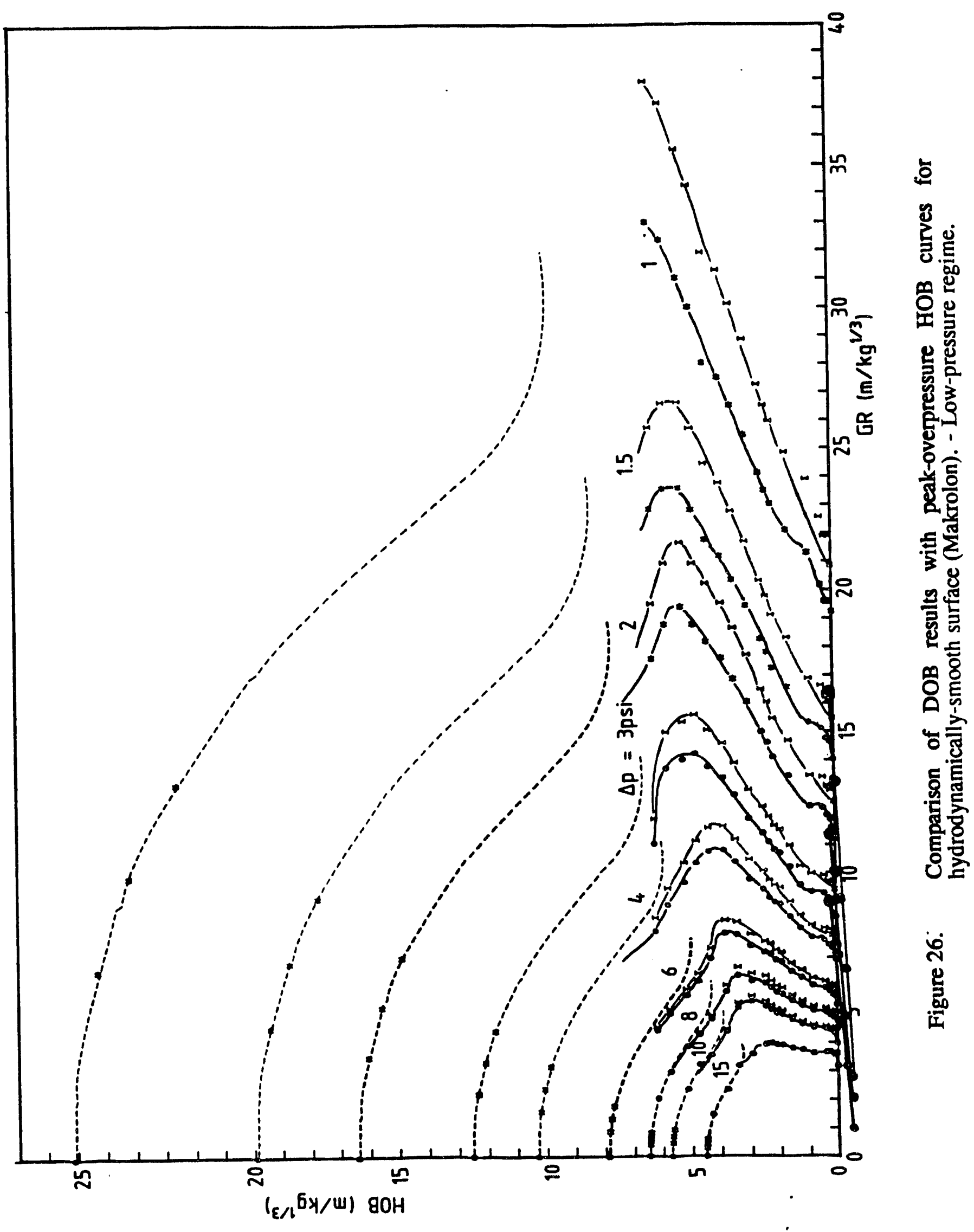




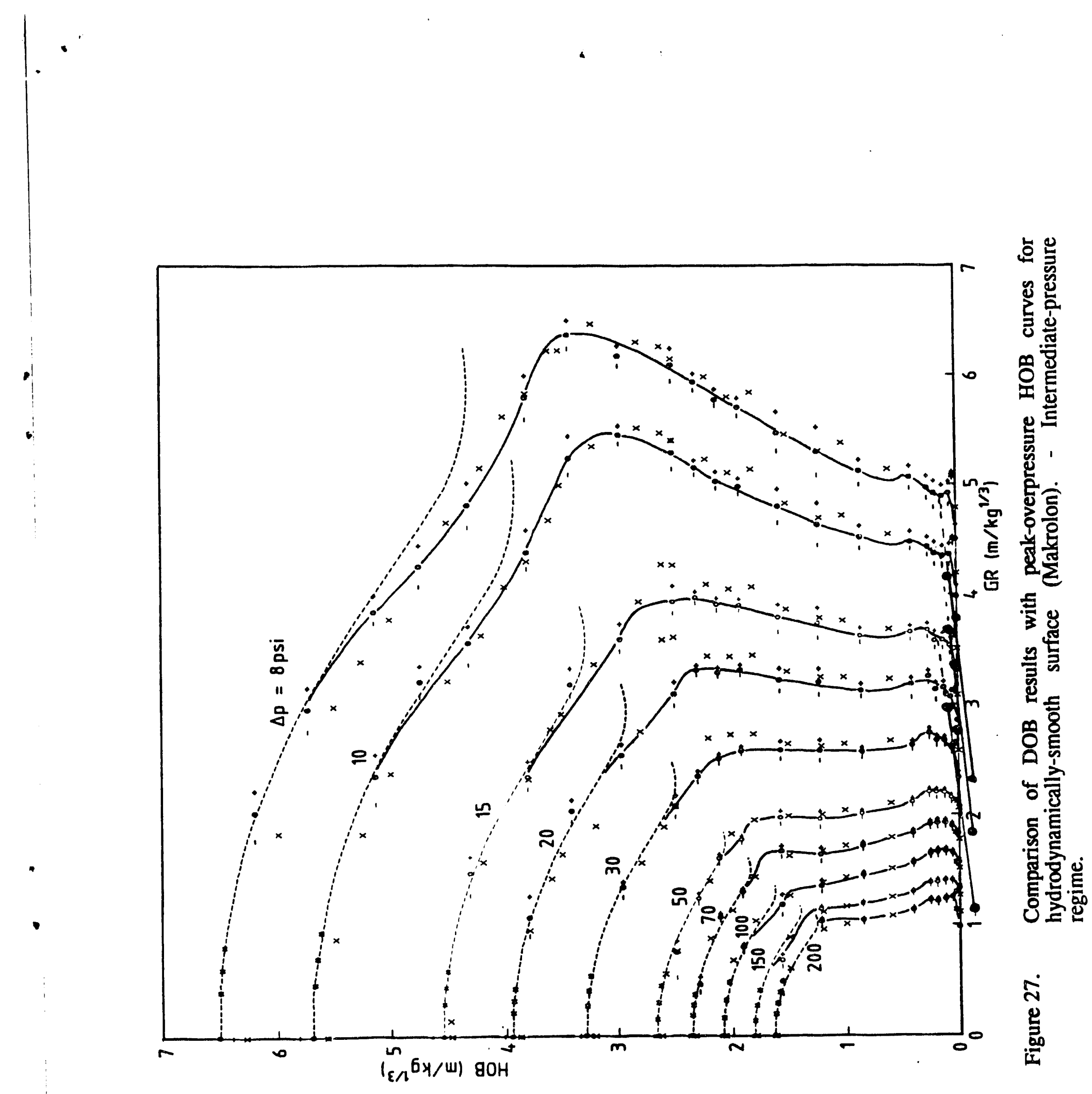



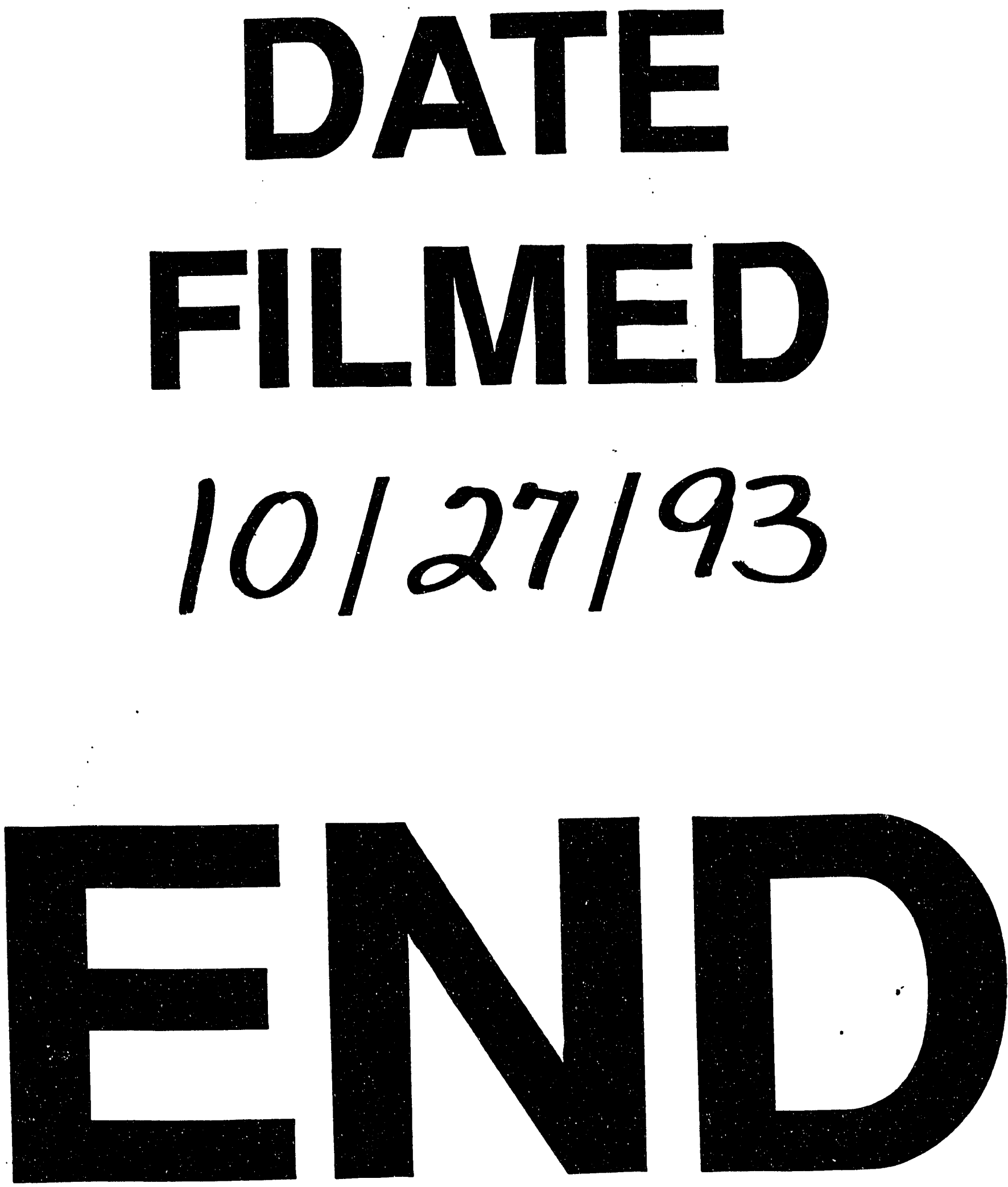
